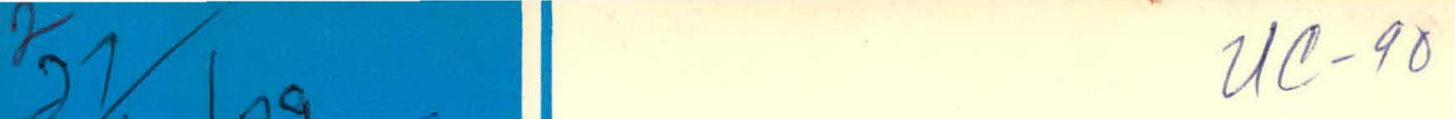

\title{
Fossil Energy Program Progress Report for April 1979
}

\author{
L. E. McNeese
}

MASTER

OAK RIDGE NATIONAL LABORATORY OPERATED BY UNION CARBIDE CORPORATION - FOR THE DEPARTMENT OF ENERGY 


\section{DISCLAIMER}

This report was prepared as an account of work sponsored by an agency of the United States Government. Neither the United States Government nor any agency Thereof, nor any of their employees, makes any warranty, express or implied, or assumes any legal liability or responsibility for the accuracy, completeness, or usefulness of any information, apparatus, product, or process disclosed, or represents that its use would not infringe privately owned rights. Reference herein to any specific commercial product, process, or service by trade name, trademark, manufacturer, or otherwise does not necessarily constitute or imply its endorsement, recommendation, or favoring by the United States Government or any agency thereof. The views and opinions of authors expressed herein do not necessarily state or reflect those of the United States Government or any agency thereof. 


\section{DISCLAIMER}

Portions of this document may be illegible in electronic image products. Images are produced from the best available original document. 


\section{Printed in the United States of America. Available from National Technical Information Service \\ U.S. Department of Commerce 5285 Port Royal Road, Springfield, Virginia 22161 \\ Price: Printed Copy $\$ 6.00$; Microfiche $\$ 3.00$}

This report was prepared as an account of work sponsored by an agency of the United States Government. Neither the United States Government nor any agency thereof, nor any of their employees, contractors, subcontractors, or their employees, makes any warranty, express or implied, nor assumes any legal liability or responsibility for any third party's use or the results of such use of any information, apparatus, product or process disclosed in this report, nor represents that its use by such third party would not infringe privately owned rights. 
Contract No. W-7405-eng-26

\author{
FOSSIL ENERGY PROGRAM \\ PROGRESS REPORT FOR APRIL 1979
}

L. E. McNeese

Program Director

Date Published - May 1979

NOTICE This document contains information of a preliminary nature. It is subject to revision or correction and therefore does not represent a final report.

\author{
OAK RIDGE NATIONAL LABORATORY \\ Oak Ridge, Tennessee 37830 \\ operated by \\ UNION CARBIDE CORPORATION \\ for the \\ DEPARTMENT OF ENERGY
}

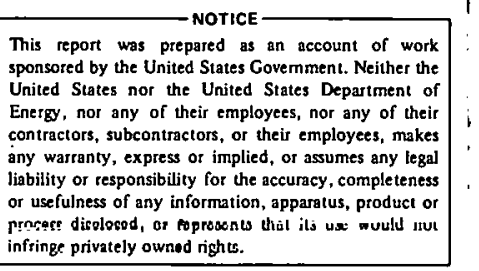
infringe privately ownod rights.
ing 
THIS PAGE

WAS INTENTIONALLY

LEFT BLANK 
ABSTRACT. . . . . . . . . . . . ............ 1

1. SUMMARY.......................... . . . . 1

2. COAL CONVERSION DEVELOPMENT. . . . . . . . . . . . . . . 5

2.1 Physical Properties of Coal Liquids . . . . . . . . . 5

2.2 Coal Slurry Preheaters. . . . . . . . . . . . 6

2.3 New Liquefaction Techniques . . . . . . . . . . . 8

2.4 In-P1ant Environmental Monitors . . . . . . . . . . . . 12

2.5 Experimental Engineering Support of In Situ
Gasification Processes. . . . . . . . . . . . . . 14

2.6 References for Section 2. . . . . . . . . . . . 19

3. CHEMICAL RESEARCH AND DEVELOPMENT. . . . . . . . . . . . 21

3.1 Chemistry and Structure of Coal . . . . . . . . . . . . 21

3.2 Kölbe1 Process Concepts . . . . . . . . . . . . 22

4. MATERIALS ENGINEERING. . . . . . . . . . . . . . . . 23

4.1 Pressure Vessel and Piping Materials. . . . . . . . . . 23

4.2 Fossil Energy Welding and Cladding Development. . . . . . 23

4.3 Fireside Corrosion of AFBC Tubes. . . . . . . . . . . . . 24

4.4 Failure Prevention and Analysis . . . . . . . . . . . . . 24

4.5 Materials for $\mathrm{ZnCl}_{2}$. Liquefaction Process. . . . . . . . 25

4.6 Materials to Resist Stress-Corrosion Cracking in
Coal Liquefaction Pilot Plants. . . . . . . . . . . 25

4.7 Development of Advanced $9 \mathrm{Cr}-1$ Mo Structural Steel. . . . 26

4.8 Ceramic Recuperators (Heat Exchangers). . . . . . . . 26

4.9 References for Section 4. . . . . . . . . . . . 27

5. COAL EQUIPMENT TEST PROGRAM. . . . . . . . . . . . . . 28

5.1 Coal Feeder Test Program. . . . . . . . . . . . . . . . . 28

5.2 Survey of Industrial Capability for Coal Handling Equipment .................. . . . . 28

5.3 Support for the Solvent Refined Coal Project. . . . . . 28

6. ENGINEERING STUDIES AND TECHNICAL SUPPORT. . . . . . . . . . 30

6.1 Process Modeling. . . . . . . . . . . . . . . . 30

6.2 Coal Liquefaction Advanced Research Digest. . . . . . . . 31

6.3 Survey of Industrial. Coal Conversion Equipment

6.4 Environmental Controls for Low-Btu Gasification . . . . $\quad 33$

6.5 SRC R\&D Assessment. . . . . . . . . . . . . . . 33

6.6 Fuel-Grade Methanol Synthesis Technology Assessment . . . 34

6.7 Liquefaction Technology Assessment. Study (LTAS) . . . . 36

7. PROCESS AND PROGRAM ANALYSIS . . . . . . . . . . . . . 39

7.1 In Situ Coal Gasification . . . . . . . . . . . . . . 39

7.2 HYGAS Modeling. . . . . . . . . . . . . . 40 
$7: 3$ Liquefaction. . . . . . . . . . . . . . 40

7.4 High Btu Gas. .. . . . . . . . . . . . . . . . 41

7.5 Direct Combustion................. 43

7.6 Advanced Power Conversion Systems . . . . . . . . . 44

8. FOSSIL ENERGY ENVIRONMENTAL PROJECT. . . . . . . . . . . . 45

8.1 Stored Solids Study . . . . . . . . . . . . . . . 45

8.2 Coal Conversion Demonstration Projects. . . . . . . . . 46

8.3 Gasification Test Facility (GTF). . . . . . . . . . . . 47

8.4 Atmospheric Fliudized Bed Combustion (AFBC) . . . . . . . 47

8.5 Processing of Coal Conversion Wastes for Disposal and Resource Recovery .. . . . . . . . . . . . . 47

9. MAGNETIC PREPARATION OF DRY CRUSHED COAL . . . . . . . . . 49

9.1 ubjectivie . . . . . . . . . . . . . . . . . 49 4

9.2 Status Summary. . . . . ............ . . .

10. ATMOSPHERIC FLUIDIZED BED COAL COMBUSTOR FOR COGENERATION (AFBCCC). . . . . . . . . . . . . . 50

10.1 Objective . . . . . . . . . . . . . . . . 50

10.2 Status Summary. . . . . . . . . . . . . 50

11. TENNESSEE VALLEY AUTHORITY (TVA) FLUIDIZED BED COMBUSTION (FBC) DEMONSTRATION PLANT PROGRAM TECHNICAL SUPPORT. . . . . . . . 51

11.1 AFBC Technology Support - Task 2. . . . . . . . . . . . . . 51

$11.24 \times 4$ Cold Flow Model - Task 3. . ... . . . . . . . . 52

11.3 AFBC Modeling and Simulation - Task 4......... 53

11.4 AFBC Bcnch Scale Mode1 - Task 5: . . . . . . . . . . 54

11.5 Assessment of the State-of-the-Art of PFBC Systems - Task 6.................... 55

11.6 Analytical Support and Alternate Des1gn Concepts Evaluation - Task 7.................. 55

11.7 AFBC Technical Source Book and R\&D Evaluation - Task 8. . 56

11.8 Materials Support for TVA Pilot and Demonstration AFBC Plants - Task 9. . . . . . . . . . . . . . . 56

11.9 Dynamic Modeling of the TVA Fluidized Bed Combustion Bed Plant - Task 10 . . . . . . . . . . . . . . 58

11.10 References for Chapter 11. . . . . . . . . . . 60

12. COAL COGENERATION/DISTRICT HEATING PLANT ASSESSMENT. . . . . 61

12.1 nhjective . . . . . . . . . . . . . . . . . . . 61

12.2 Status Summary................... 61

13. FBC INDUSTRIAL APPLICATIONS PROJECT SURVEY . . . . . . . . 62

13.1 Objective . . . . . . . . . . . . . . . . 62

13.2 Status Summary. . . . . . . . . . . . . 62 


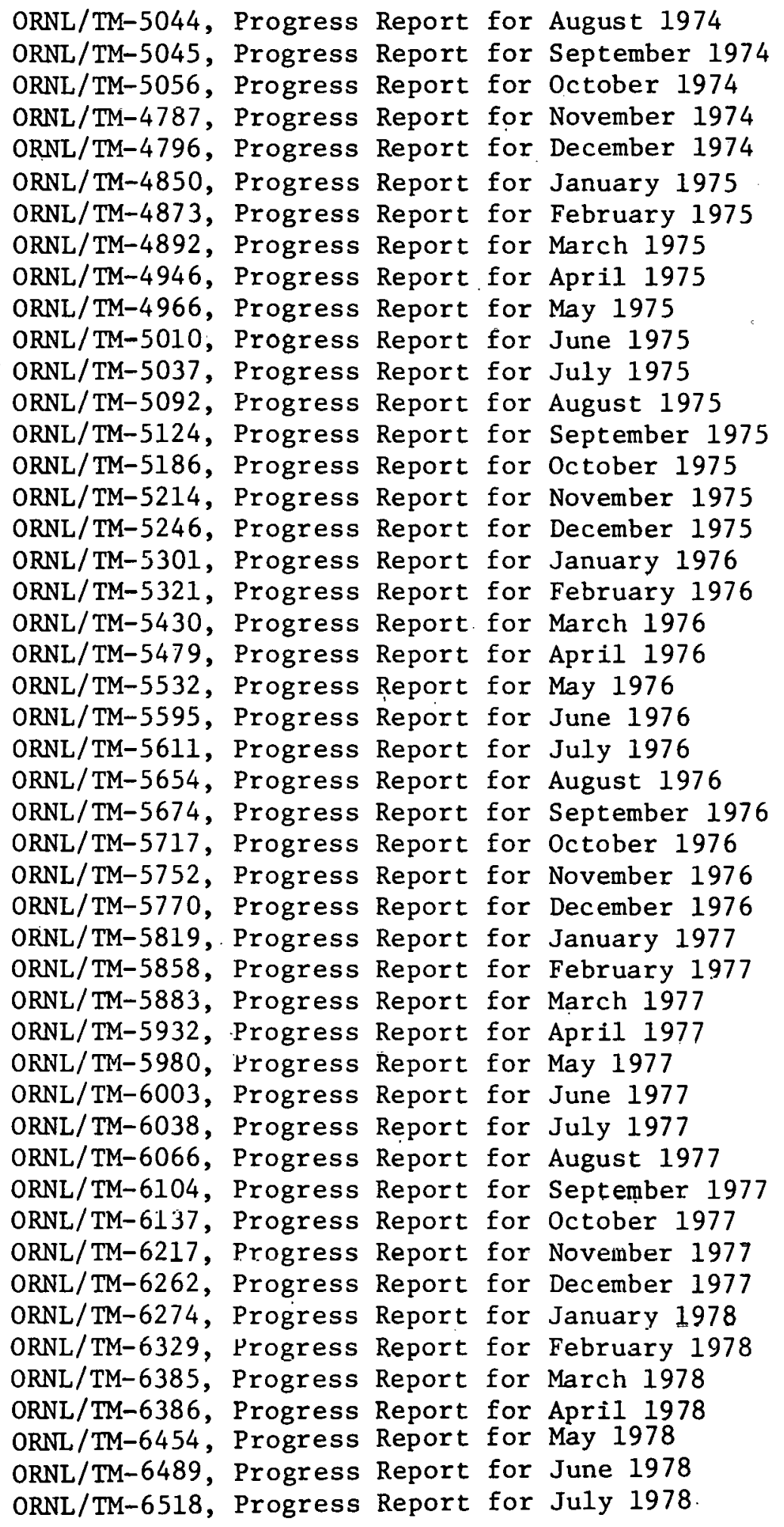


PREVIOUS REPORTS IN THIS SERIES (CONTINUED)

ORNL/TM-6592, Progress Report for August 1978

ORNL/TM-6630, Progress Report for September 1978

ORNL/TM-6666, Progress Report for October 1978

ORNL/TM-6682, Progress Report for November 1978

ORNL/TM-6767, Progress Report for December 1978

ORNL/TM-6815, Progress Report for January 1979

ORNL/TM-6829, Progress Report for February 1979

ORNL/TM-6886, Progress Report for March 1979 
FOSSIL ENERGY PROGRAM REPORT FOR APRIL 1979

\section{ABSTRACT}

This report - the fifty-seventh of a series - is a compendium of monthly progress reports for the ORNL research and development programs that are in support of the increased utilization of coal and other fossil fuel alternatives to oil and gas as sources of clean energy. The projects reported this month include those for coal conversion progress development, chemical research and development, materials engineering, a coal equipment test program, engineering studies and technical support, process and program analysis, environmental assessment studies, magnetic beneficiation of dry pulverized coal, an atmospheric fluidized bed combustor for cogeneration, technical support to the TVA fluid bed combustion program, coal cogeneration/district heating plant assessment.

\section{Summary}

L. E. McNeese

Highlights of our progress in April are as follows:

Coal Conversion Development - Electrical problems in the 1iquid level controller for the Coal Liquids Flow System's vapor-liquid separator prevented rheological characterization measurements during a one-week operating period this month. These problems were subsequently corrected. The Norcross falling ring viscometer, modified for improved slurry operation, operated satisfactorily on a high viscosity slurry. Analysis of heat transfer data from the previous slurry preheater measurements continued. Analysis has begun using gel permeation chromatography to determine molecular weight distributions of the products from the thermal reaction of Wyodak coal and phenol: As reaction temperature increases there appears to be an increase in the maximum molecular weight observed in the products and an increase in the product's molecular weight range. The prototype portable electronics module for the PNA."spill spotter" was completely assembled and successfully operated with the optics unit for the first time. Experiments and analyses in support of underground coal gasification (UCG) produced results from block pyrolysis of bituminous coal in an atmosphere of simulated UCG product gas. Physical property measurements on coal blocks are discussed.

Chemical research and development - The four primary products from the pyrolysis of bibenzyl at $2400^{\circ} \mathrm{C}$ have now been rigorously identified. Three additional secondary products which appear only at higher conver- 
sions have also been identified. Hence our description of bibenzyl pyrolysis is now virtually complete. Initial studies have been made of the perturbing effect of added phenol. The chemical assessment of the possible impact of Kölbel process concepts on advanced processes for indirect liquefaction has begun.

Materials Engineering - The characterization of $21 / 4 \mathrm{Cr}-1$ Mo stee 1 given various heat treatments to simulate the properties of thick sections was continued. Both tensile and Charpy tests showed that aging at $343^{\circ} \mathrm{C}$ for $1000 \mathrm{~h}$ had no effect on specimens that had been previously slow cooled, tempered, and stress relieved; however, similar aging of specimens that had been fast cooled, tempered, and stress relieved improved their notch toughness. In the task on weld overlay cladding, a draft of the report entitled Cladding of $21 / 4 \mathrm{Cr}-1$ Mo Steels With Type $320 \mathrm{Cb}$ Stainless Steel was completed and submitted for technical editing and review. Examination of the final five tubes exposed at high temperature in the 4500-h test in the FluiDyne atmospheric fluidized-bed combustor is in progress. In the fallure prevention and analysis task, the report on the first two sets of corrosion coupons from the Wilsonville solvent-refined coal pilot plant is being revised to incorporate comments received from Catalytic, Inc. A third set of coupons from the Wilsonville dissolver was examined for stress-corrosion cracking, but no evidence of such was found. Metallographic examination of the vessel walls and internals of the Wilsonville T105 fractionation column showed the corrosion attack to be intergranular. Inspection revealed the column to be damaged more than first presumed, with the type 304 stainless steel liner no longer able to protect the mild steel walls. The examination of the U-bend specimens exposed at the Fort Lewis solvent-refined coal pilot plant is in progress. Other specimens are presently being exposed at Wilsonville and Fort Lewis. Mechanical property characterization and fabrication, weldability, and steam corrosion studies continued on the small experimental heats and two intermediate-size heats of modified $9 \mathrm{Cr}-1$ Mo steel. Bids for the preparation of two large commercial heats have not yet been received. Efforts are continuing to place a subcontract with Hague International for evaluation of silicon carbide heat exchangers exposed to the combustion products of coal-oil mixtures. Designs of ceramic heat exchangers for use in the steel, aluminum, and glass industries are expected from Garrett-AiResearch next month. Modifications to the refractories test facility at ORNL to permit testing of candidate ceramic heat exchanger materials is proceeding on schedule.

Coal Equipment Test Program - A presentation was made to program personnel at Morgantown (METC) on the results of the feasibility study and planning estimate for the Dry Coal Feeding/Handling Facility. The final report should be issued in May. Approximately half of the equipment survey report has been completed in rough draft form. A rough draft of Bechtel National's report to us, promised by May 8 , is needed to complete the ORNL report. Visits to the Exxon Donor Solvent experimental facility at Baytown, Texas, and the SRC Pilot Plant at Wilsonville, Alabama, were made to learn of their experience with pumps, compressors, valves, and instrumentation. 
Engineering Studies and Technical Support - An evaluation of fuel-grade methanol synthesis technologies is approximately $50 \%$ completed, with information on currently commercial and previously commercial processes being developed through vendor contacts, . literature and patent searches, and discussions with process developers. A judgmental assessment of relative technical and economic potential of the processes will be performed next month.

Process and Program Analysis - The IGT HYGAS pilot plant Test' Run No. 78 has been evaluated by Scientific Design Company, following the post-run examination which began March 15. Despite high superficial velocity and mild SOG temperatures, clinkering appears to have occurred in the gasification section before the test was terminated as a result of insurmountable solids transfer problems and leaks in the quench/slurry system.

In the Fossil Energy Environmental Project, physical and chemical characterization of Grace solid waste was completed. Technical assistance was provided to DOE on six demonstration plants: SRC-I, SRC-II, Grace, MLGW, CONOCO, and ICGG. The Notice of Intent to prepare an environmental impact statement and the Implementation Plan for the Grace project were prepared and transmitted to DOE for publication in the Federal Register.

Magnetic Beneficiation of Dry Crushed Coal - Satisfactory operation of the laboratory superconducting magnet was witnessed at the manufacturer's plant.

A second TVA engineer has been assigned to our laboratory to conduct an experimental program.

A mathematical model of the free-fall open-gradient magnetic separation is operational and has been experimentally verified.

Atmospheric Fluidized Bed Coal Combustor for Cogeneration (AFBCCC) Interest is running very high in the CCC Program RFP and a large number of proposals are now expected. The proposal submlssion deadiine has been extended to May 31 , and all the prospective vendors have been notified.

TVA FBC Demonstration Plant Program - Preliminary fluidized bed slumping tests have been conducted on the ORNL cold flow model. Cooperation with MIT in the steady-state modeling of the AFBC is continuing. MIT has agreed to run ORNL's input data on the full MIT combustor code. Additional instrumentation has been fitted to the AFBC bench scale combustor and the limestone feeder is nearing completion. A steam power plant model and interface with pressurized fluidized bed combustors has been completed and tested. Available literature on existing $R \& D$ facilities has been reviewed for use in compiling the AFBC technical source book. Samples of heat-exchanger material from the Leatherhead, England, combustor have been obtained and are undergoing examination. The dynamic model of the TVA AFBC demonstration plant has undergone further testing successfully. 
Coal Cogeneration/District Heating Plant Assessment - Additional contractual problems with United Engineers and Constructors arose but appear to have been resolved. The in-house cogeneration cycle analysis has resulted in a configuration for a combined cycle plant with a maximum gross electrical efficiency of about $46 \%$.

FBC Industrial Applications Project Survey - No reviews were made for this past month. 


\section{COAL CONVERSION DEVELOPMENT}

J. R. Hightower, Jr.

Coal conversion development activities are carried out in the Chemical Technology Division. This section discusses four projects conducted for the Division of Fossil Fuel Processing -- Physical Properties of Coal Liquids, Coal Slurry Preheaters, New Liquefaction Techniques, and In-Plant Environmental Monitors -- and one project conducted for the Division of Fossil Fuel Extraction -- Experimental Engineering Support for In-Situ Gasification Processes.'

\subsection{Physical Properties of Coal Liquids}

G. E. Oswald, M. R. Gibson, and E. L. Youngblood

Physical properties (viscosity, density, thermal conductivity, and heat capacity) of both coal-solvent slurries and solids-free, coalderived liquids will be measured at typical processing conditions, up to $31 \mathrm{MPa}(4500 \mathrm{psig})$ hydrogen pressure and $810 \mathrm{~K}\left(1000^{\circ} \mathrm{F}\right)$ in a benchscale, continuous flow system. The system includes a slurry preheater section and a hydrogenation reactor to simulate processing conditions prior to physical property measurement. Immediately after physical property measurement, the test fluids will be quenched and sampled for chemical characterization. Physical properties will be correlated with chemical characteristics of the test liquid.

Work accomplished. The CLFS was operated for one week to train additional personnel as system operators. Rheological characterizations on $35 \mathrm{wt} \%$ slurry scheduled during this period were canceled when problems developed with the high pressure/high temperature vapor-1iquid separator liquid level probe. An insulator in the probe had cracked resulting in erratic operation; the probe will be repaired for the next operation period in early May.

The Norcross falling ring viscometer was callbrated using the modified ring with increased internal diameter. The internal diameter of the ring was increased to permit passage of the largest coal particle $(100 \mu \mathrm{m})$ in the slurry. Before this modification was made, the ring would become jambed on the centerpost when coal particles lodged between the ring and the post. Mixtures of mineral oil and dodecane were used as the calibration liquids. Due to the increased flow area resulting from the increase in ring internal dlameter, the low viscosity measurement limit of the instrument is now $1 \mathrm{MPa} \cdot \mathrm{s}$ ( $1 \mathrm{cp}$ ) versus $0.1 \mathrm{MPa} \cdot \mathrm{s}$ ( $0.1 \mathrm{GP})$ prior to modification. The hlgh viscosiey limit remains at $10 \mathrm{~Pa} \cdot \mathrm{s}(10000 \mathrm{cp})$. The viscometer was tested on a product $35 \mathrm{wt} \%$ slurry produced during earlier hydrogen operations at $700 \mathrm{~K}\left(800^{\circ} \mathrm{F}\right)$ preheater discharge and $13.9 \mathrm{MPa}$ (2000 psig) system pressure. The viscometer was operated at room temperature and atmospheric pressure for 48 hours with no sign of ring hang-up on the center post or of settled 
solids imparing ring movement. Future tests at elevated temperature will be more severe because the tendancy for solids to settle out of the slurry will increase as viscosity decreases. During some previous tests with slurry, settled solids have impaired ring movement.

Design for an improved high pressure/high temperature vapor-liquid separator has been initiated. Improvements over the present separator include increased cross-sectional area for disengagement and provisions for use of either the capacitance liquid level probe or a purged dip tube differential pressure liquid level monitor.

The hydrogen booster compressor has been repaired and installed at the compressor station.

Future work. Objectives for the next operation period will be replicate slurry rheologlcal characlerlzatiuns aud pipeline viscometor measurements in the slurry gel formation region $(>550 \mathrm{~K})$.

The Norcross falling ring viscometer will be evaluated for viscosity measurements on slurry at elevated temperature. The gamma ray absorption liquid density instrument will be calibrated and incorporated into the system flow configuration.

\subsection{Coal Slurry Preheaters}

J. R. Thurgood and E. L. Youngblood

In coal IIquefaction processes using slurries, such as the SRC processes, preheaters are used to heat the slurry or slutly-liydrogen mixture to about $700 \mathrm{~K}\left(800^{\circ} \mathrm{F}^{\prime}\right)$. During preheatlug, cual dissolution and chemical reactions occur which change the properties and flow characteristics of the slurry. These changes are not well understood and result in difficulties in the design and operation of preheaters. This work is aimed specifically toward improved process understanding and focuses on the thermal and rheological characterlstics of slurry flow in the preheater at preheater conditions [pressures up to $31 \mathrm{MPa}$ $(4500 \mathrm{psig})$ and temperatures up to $\left.810 \mathrm{~K}\left(1000^{\circ} \mathrm{F}\right)\right]$. The effort interfaces with and utilizes results from a companion project on "Physical Properties of Coal Liquids" which is also being conducted at the Oak Ridge National Laboratory.

During this report period preparations were made for slurry rheo-. logical characterizations in the temperature range of 550 to $700 \mathrm{~K}$. Difficulties were encountered in running the planned experiments because of a failure in the level control probe of the vapor-liquid separator. other work conducted included minor equipment modifications, interfacing of measurement and recording equipment with a DEC PDP-11 computer, and continued analysis of the heat transfer data from previous experiments. 


\subsubsection{Experimental work}

Rheological characterizations of 35 wt \% Illinois No. 6 coal/ Wilsonville recycle solvent slurry had been made previously at temperatures of $400,478,500$, and $550 \mathrm{~K}$. Also a few data points had been collected at $700 \mathrm{~K}$. Preparations were therefore made to make characterizations at 600 and $700 \mathrm{~K}$ and to check out reproducibility of the data at one of the preceding temperatures. The Illinois No. 6. coal was pulverized and screened to $98 \%$ through a 170 mesh screen. Consideration is presently being glven to purchasing commercially ground coal in order to ensure better control and uniformity of particle size distribution from one batch of coal to the next. Several minor equipment modifications were also made to improve system operation and to improve parameter measurability. A $0.200 \mathrm{in}$. ID line was installed to replace the $0.109 \mathrm{in}$. ID line which ran from the dissolver to the vapor l1quid separator. This change was made to reduce plugging tendencies in this section of the system. Also, the pipeline viscometer dp cell was repositioned to minimize the possibility of gas holdup in the cell legs so as to enable more accurate measurement of the pressure drop across the viscometer. Finally, the repaired high pressure stage of the hydrogen compressor was received and installed.

After the experimental preparations were completed a slurry test was started. However, the liquid level control system began to malfunction and finally stopped working altogether before any data were collected. Upon investigation the level control probe was found to be inoperable. The probe has since been repaired and a new replacement probe has been made. Experimentation is scheduled to resume again at the beginning of the next report period.

A DEC PDP-11 computer has been interfaced with the CLFS control panel and is wired to $\log$ in various temperature readings (18 different preheater temperatures and the inlet and outlet temperatures of the pipeline viscometer) and the accumulative time that power is going to the preheater heating tapes. An interface to the pipeline viscometer dp cell and one to the feed pot weigh cell are soon to be installed also. Software has been written to accept and translate the analog and digital signals received and programs are being written to reduce the data for flow curve and rheogram plots. Programs for heat transfer data logging and analysis are also in preparation.

Continued consideration is being given to analysis of heat transfer data and to ways of correlating the data with the operating parameters and with the rheological data. This information will be reported as it i.s developed.

\section{2 .2 Work forecast}

Work forecast for the next report period includes: (1) characterizing slurry rheology at temperatures from 600 to $700 \mathrm{~K}$, (2). testing of combined phase hydrogen-slurry flow, and (3) completing the interfacing of the viscometer dp cell and the feed pot weigh cell to the computer. 


\subsection{New Liquefaction Techniques}

J. W. Larsen, * T. L. Sams, and B. R. Rodgers

\subsection{Molecular weight determinations of coal/phenol reaction products}

The pyridine-soluble products from the thermal reaction of Wyodak coal with phenol were subjected to gel permeation chromatography (GPC) to gather information concerning the molecular weight distribution of the products. The columns used were $\mu$-styrogel, 100,500 and $1000 \AA$ in series, with pyridine as solvent. In order to determine the molecular weight distribution, the relation between elution volume and molecular weight must be established. This has been done for these columns for material. derived from the acid-catalyzed reaction of coal and phenol at lower temperatures, but these products may be quite difierent from the products of the thermal reaction, with which we are now concerned. Accordingly, we plan to recalibrate the column, and therefore we report here only early, qualitative results. When the column has been calibrated, we shall express these results in terms of molecular weights rather than retention volumes. Table 2.1 contains the conversion data for the runs which have been chromatographed.

Figure 2.1 shows the results of a typical GPC run with a refractive index detector. The vertical axis is the difference in refractive index between the pyridine solution being eluted and pure pyridine. Its magnitude is not related linearly to the mass of material being eluted. The retention volume (horlzontal axis) is controlled primarily by the molecular weight of the solute belng eluled; the firot material pluted from the column has the highest molecular welght. A decrease in initial retention volume (the volume at which the firet material elinted appears) thus indirates an increase in the molecular weight of the largest products. Likewise the total volume over which all the products elute is a measure of the molecular weight range of the products. Once the column is calibrated, this qualitative discussion will be made quantitative.

Figure 2.2 shows a plot of initial retention time vs cunversion and of total elution time vs conversion. The molecular weight of the highest molecular weight products decreases as conversion increases. The molecular weight range first increases but then decreases sharply so that at conversions above $60 \%$, the range of molecular weights has narrowed. This is due in part to a decrease in the high molecular we1ght material.

As the reaction temperature increases, there appears to be an increase in both the molecular weights of the highest molecular weight products and in the molecular weight range.

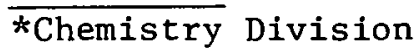


Table 2.1. Reaction conditions and GPC retention times for coal-phenol products

\begin{tabular}{|c|c|c|c|c|c|}
\hline $\begin{array}{l}\text { Conversion } \\
(\%)\end{array}$ & $\begin{array}{c}\text { Temperature } \\
\left({ }^{\circ} \mathrm{F}\right)\end{array}$ & $\begin{array}{l}\text { Reaction } \\
\text { time } \\
\text { (min) }\end{array}$ & $\begin{array}{c}\text { Phenol/coal } \\
\text { ratio }\end{array}$ & $\begin{array}{c}\text { Initial retention } \\
\text { time } \\
\text { (min) }\end{array}$ & $\begin{array}{c}\text { Total elution } \\
\text { time } \\
\text { (min) }\end{array}$ \\
\hline 64 & 800 & 10 & 15 & 14.0 & 12.3 \\
\hline 59 & 850 & 10 & 10 & 13.5 & 14.2 \\
\hline 49 & 900 & 5 & 15 & 13.4 & 14.6 \\
\hline 39 & 800 & 15 & 15 & 13.3 & 13.0 \\
\hline 37 & 900 & 15 & 5 & 13.1 & 13.5 \\
\hline
\end{tabular}

Note: The elution flow rate used was $1.5 \mathrm{ml} / \mathrm{min}$. 


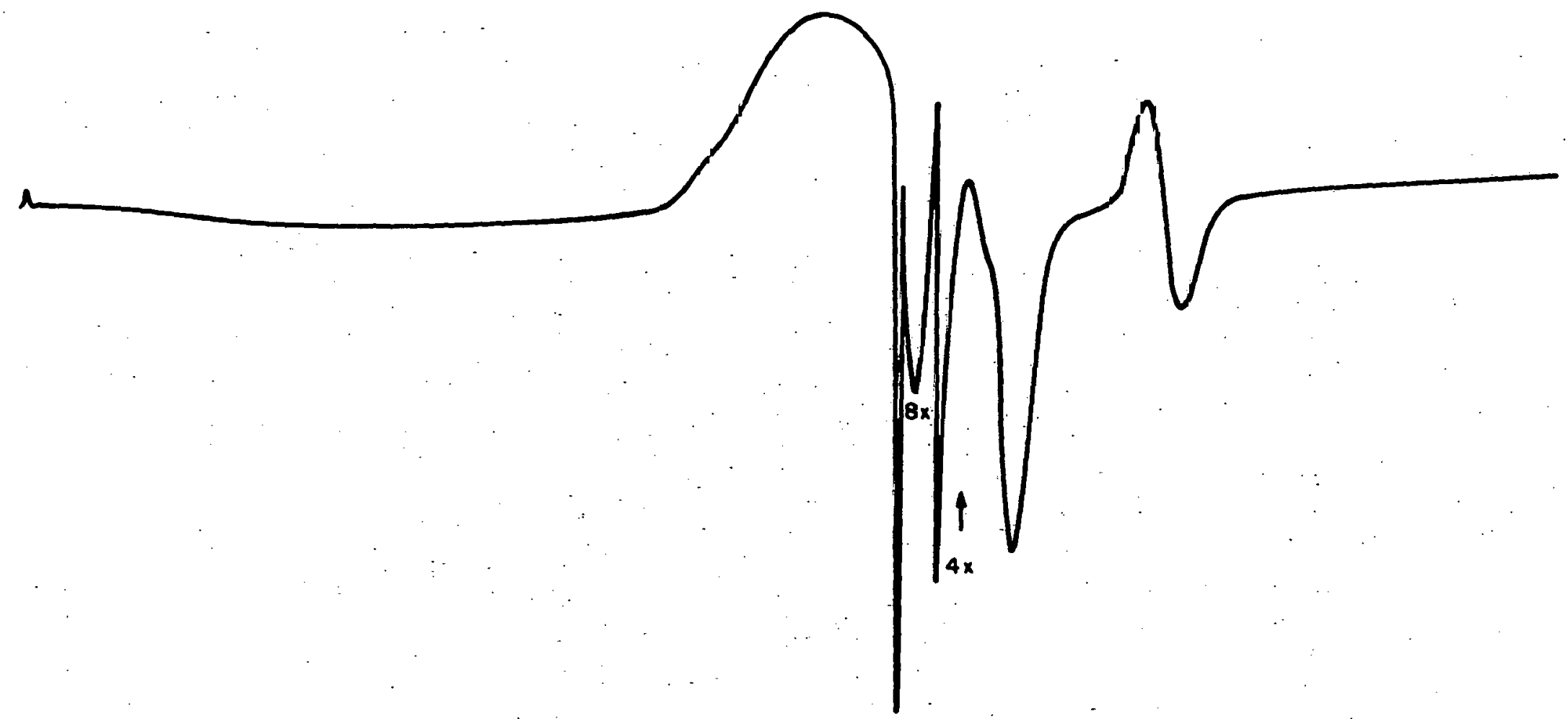

Pig. 2.1. Typica- Ge1 Permeation Chromatography 


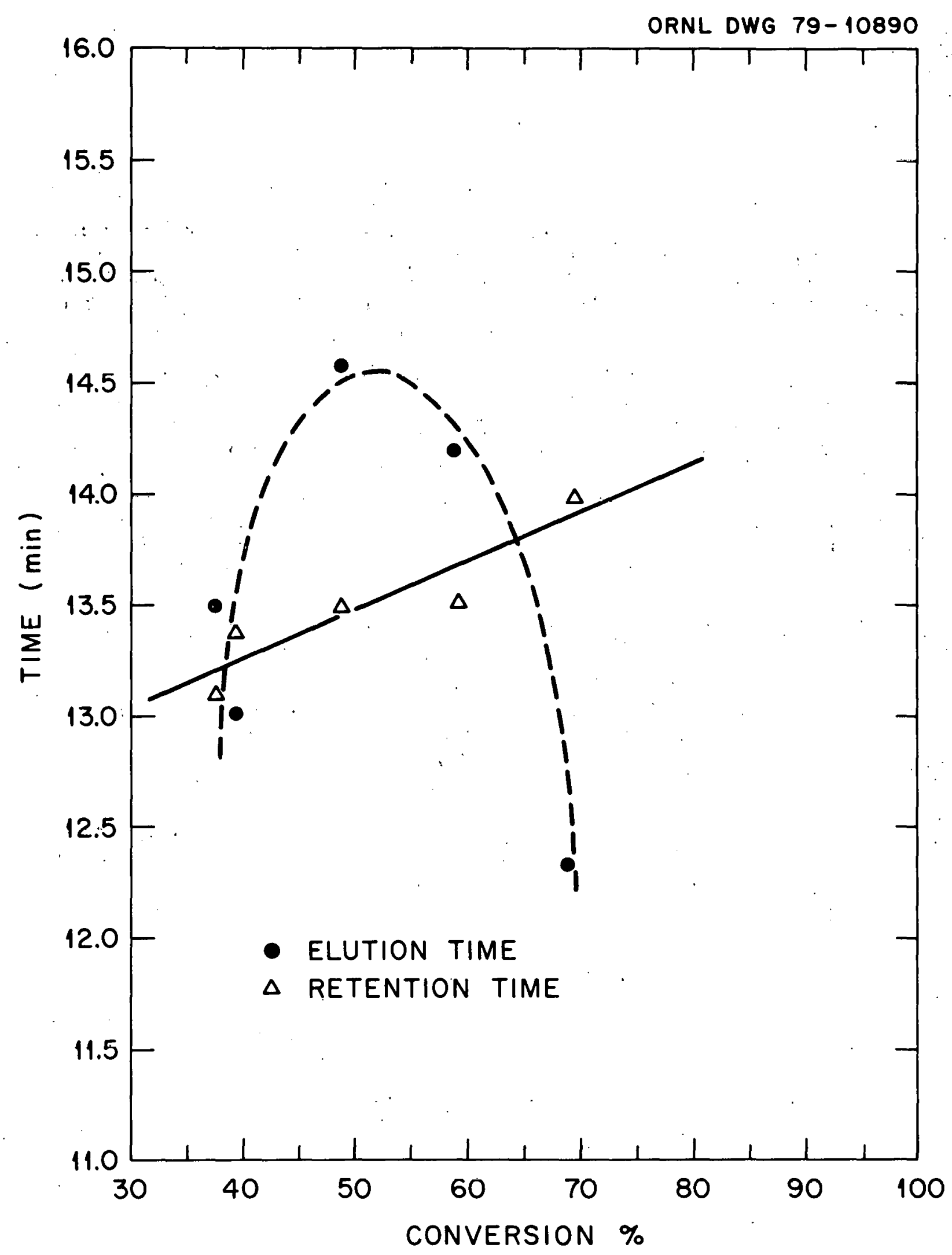

Fig. 2.2. Initial retention time and total elution time vs conversion. 


\subsection{In-Plant Environmental Monitors}

D. D. Schuresko, G. K. Schulze,* and M. L. Bauer*

The prototype portable electronics module for the PNA spill spotter was completely assembled and successfully operated with the optics heads for the first time during April. Various bugs in the arc lamp regulator and igniter circuit and in the chassis wiring were corrected. The LCD digital panel meter was destroyed by rf pick up from the arc lamp ignition pulse and was temporarily replaced by an analog panel meter. Protection circuitry is being designed to shield the LCD meter from this pulse.

The initial veroion of the lamp igniter and regulator circuit is shown in Figure 2.3. The arc lamp current is measured with the $0.1 \mathrm{ohm}$, 3 watt resistor connected to the negative lamp lead. The voltage drop across this resistor feeds into the $\mu \mathrm{A} 723 \mathrm{c}$ regulator chip which controls the collector-emitter resistance of the MJE901 pass transistor. This series regulator circuit has been slightly modified ${ }^{1}$ by connecting a $2 \mathrm{ohm}, 25$ watt resistor across the MJE901 to provide larger current to the arc lamp immediately after ignition. The oscillator circuit, consisting of the (2) 2 N4296 transistors cross coupled by the coils of transformer TY89, is activated by depressing the start push button. It feeds a 600 VAC signal to the rectifier, doubler, and filter network incorporating the 1 N4006 diodes, which charges up the $0.33 \mu \mathrm{fd}$, $600 \mathrm{~V}$ capacitor connected to the primary of transformer $\mathrm{T} 2$. The oscillator output is also clipped by the 1N4004 diode pair and fed to the positive lamp terminal; thus the supply open circult voltage. is boosted to 70 volts for lamp ignition. The $0.33 \mu \mathrm{fd}, 600 \mathrm{~V}$ capacitor is discharged through the primary of $\mathrm{T} 2$ by firing the C137PB silicon controlled rectifler (SCR), which is triggered by a $30 \mathrm{~Hz}$ pulse train from the 555 timer circuit. The SCR discharge is stepped up to $5 \mathrm{KV}$ in the secondary coil of $\mathrm{T} 2$ and breaks down the arc lamp residual gas for ignition. The current surge provided from the discharge of the $10 \mu \mathrm{fd}$, $150 \mathrm{~V}$ capacitor, which has been charged to $70 \mathrm{~V}$ by the oscillator, serves to get the arc going.

Recent modifications to this original design have included replacement of the start pushbutton by a single pole pushbutton which again activates the oscillator and the 353 Lfmer clrcull. A $0.22 \mu[d$ capacitor was connected between the negative lamp terminal and common to prevent the lamp ignition pulse from feeding back into the regulator. The modified version lights arc lamps quite reliably, and thus will be duplicated for the field testing unit electronic modules.

\footnotetext{
*Instrument and Controls Division
} 


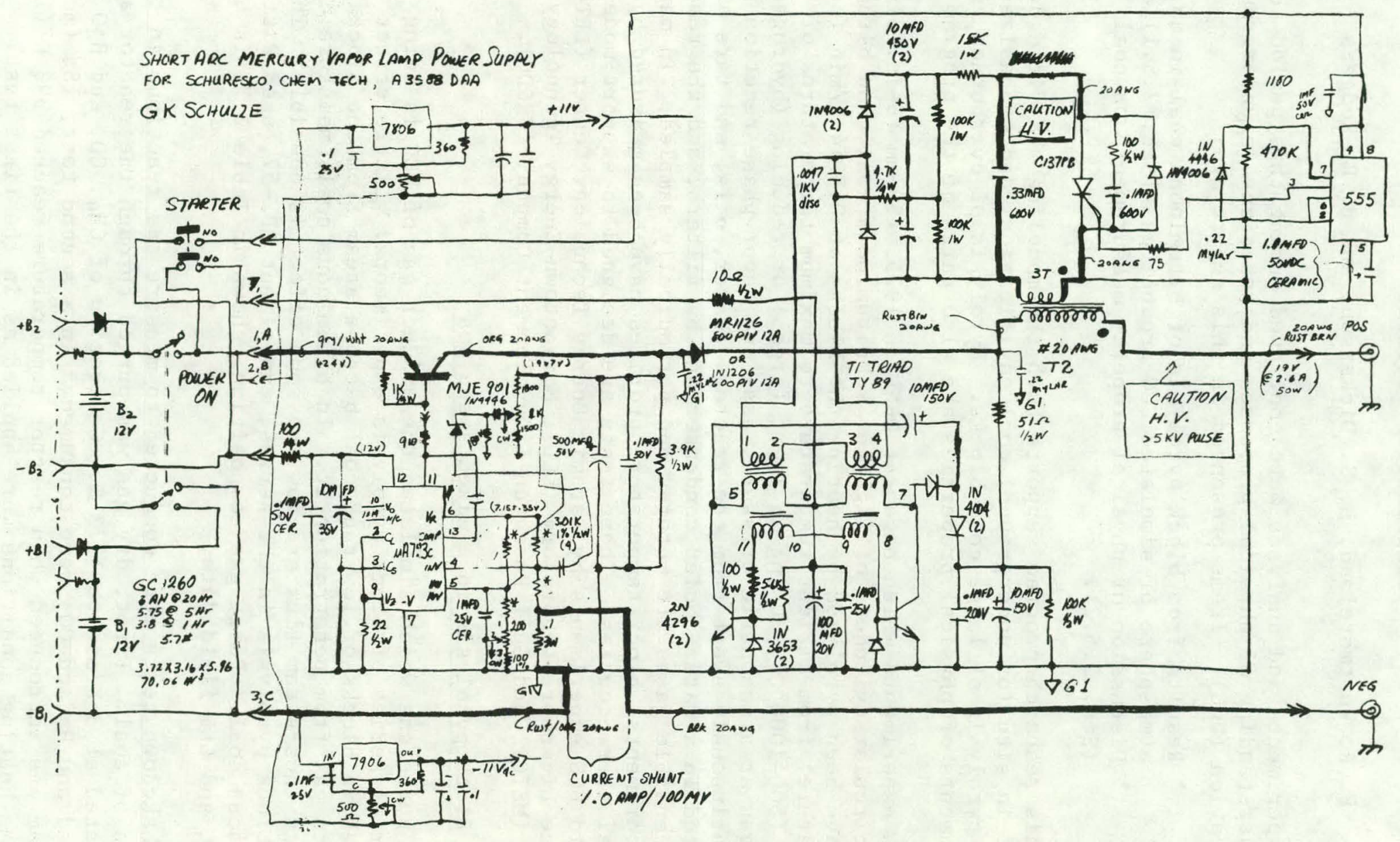

Fig. 2.3. Arc lamp power supply. 


\subsection{Experimental Engineering Support of In Situ Gasification Processes}

P. R. Westmoreland, L. S. Dickerson, and B. R. Rodgers

Experiments and analyses were continued during this period to improve the understanding of physical processes and reactions in underground coal gasification (UCG). Items presented in this report are:

- Results from block pyrolysis of bituminous coal in an atmosphere of simulated UCG product gas (Sec. 2.5.1) and

- Discussion of physical property measurements on coal (Sec. 2.5.2).

This research program supports both the modeling and field development of in situ (or underground) coal gasification, and emphasizes study of the pyrolysis of large coal blocks. Pyrolysis of overburden and measurements of physical properties are also parts of the program.

In experiments which began at ORNL in 1975, 150-mm (6-in.-diam) right circular cylinders of lignite, subbituminous coal, and bituminous coal have been pyrolyzed by heating the blocks at $0.3-14 \mathrm{~K} / \mathrm{min}$ (surface temperature) from ambient temperature to maximum temperatures of 773$1273 \mathrm{~K}\left(500-1000^{\circ} \mathrm{C}\right)$. Using an inert (argon) or reducing (hydrogen) purge gas at atmospheric pressure, gas- and vapor-phase reaction products are continuously swept from the reactor. Water, oils, and tars are collected in a water-cooled condenser and by filters, and the remaining noncondensible gases are metered and periodically sampled. In many of the experiments, block temperature profiles have been measured by internal thermocouples. These tests are designed to support modeling of field UCG experiments by Laramie Energy 'l'echnology Center (LE'I'C), Lawrence Livermore Laboratory (LLL), Morgantown Energy 'lechnology Center (METC), and Gulf Research \& Development Company (GR\&DC).

\subsubsection{Block pyrolysis in a mixed sweep gas}

A purge gas which simulates the product gas of UCG is being used in a brief series of block pyrolysis experiments. Little effect is expected in blocks of low-rank coal because steam from the block prevents gas from penetrating it. In bituminous coal, moisture content and thus steam flux are low, so some effect is possible. The first block pyrolysis in the series, experiment BP2-57, used Pittsburgh bituminous coal. Purge gas composition, shown in Table 2.2, is based on LETC and LLL field data.

Shakedown tests were conducted to measure gas reactions in the absence of coal. First, dry gas was purged through the reactor as it was heated at $3 \mathrm{~K} / \mathrm{min}$ to $1273 \mathrm{~K}$. Generation of $\mathrm{CH}_{4}, \mathrm{CO}$, and $\mathrm{H}_{2} \mathrm{O}$ was observed and $\mathrm{H}_{2}$ and $\mathrm{CO}_{2}$ were consumed. In a second test, $18 \%$ (molar) of steam was introduced when reactor temperature reached $398 \mathrm{~K}\left(125^{\circ} \mathrm{C}\right)$; the same heating conditions were applied as in the first test. 
Table 2.2. Composition of simulated UCG sweep gas in experiment BP2-57

\begin{tabular}{lcc}
\hline & \multicolumn{2}{c}{ Composition (mo1 \%) } \\
\cline { 2 - 3 } Gas & Dry basis & Wet basis \\
\hline $\mathrm{H}_{2}$ & 16.70 & 14.2 \\
$\mathrm{CH}_{4}$ & 3.89 & 3.3 \\
$\mathrm{CO}$ & 13.92 & 11.8 \\
$\mathrm{CO}_{2}$ & 13.78 & 11.7 \\
$\mathrm{Ar}^{\mathrm{a}}$ & 51.71 & 43.9 \\
$\mathrm{H}_{2} \mathrm{O}$ & - & 15.2 \\
\hline
\end{tabular}

a Substituted for $\mathrm{N}_{2}$.

Table 2.3. Conditions for experiment BP2-57

Coai used:

High-volatile A bituminous coal Pittsburgh seam

Monongalia Co., West Virginia

Coal cylinder:

$4.040 \mathrm{~kg}$ as-received, $3.775 \mathrm{~kg}$ maf

$146.0 \mathrm{~mm}$ diam (5-3/4 in.)

$174.6 \mathrm{~mm}$ high (6-7/8 in.)

Reactor heating rate: $3 \mathrm{k} / \mathrm{min}\left(5^{\circ} \mathrm{F} / \mathrm{min}\right)$

Maximum temperature: $1073 \mathrm{~K}\left(1472^{\circ} \mathrm{F}\right)$

Purge gas flow: $\quad 0.1396 \mathrm{~mol} / \mathrm{min}(0.1105 \mathrm{scf} / \mathrm{min})$ 
Although the gas components reacted with each other above $1073 \mathrm{~K}$, little reaction was observed below that temperature. Some carbon was produced, either by methane cracking or by the reverse Boudouard reaction (CO decomposition).

In experiment BP2-57, Pittsburgh seam bituminous coal was heated in the mixed gas to a maximum temperature of $1073 \mathrm{~K}\left(800^{\circ} \mathrm{C}\right)$. Because temperature only reached $1073 \mathrm{~K}$, only a slight correction to the gas yields is necessary. Experimental conditions are summarized in Table 2.3.

The block swelled appreciably, engulfing control thermocouples at about $620 \mathrm{~K}\left(350^{\circ} \mathrm{C}\right)$. The resulting char was roughly cylindrical at $210-\mathrm{mm}$-diam by $200-\mathrm{mm}$-high, a volume increase of $140 \%$. Inside the char block, a gas pocket and several bubbles were found in the center. Black powdery material was found on the top of the char block $(13.1 \mathrm{~g})$. in the reactor effluent line $(4.5 \mathrm{~g})$, and on the condenser coils $(116.8 \mathrm{~g})$. Some of the material was carbon, apparently deposited by gas-phase reactions. Carbonized tar may have been present on the char block, but the material in the reactor-to-condenser line was a soft tar coated with carbon particles. On the condenser coils at $288 . \mathrm{K}\left(15^{\circ} \mathrm{C}\right)$, the black powder also contained clear, colorless crystals, but all the material scraped from the coils melted into soft tar at room temperature. All these materials were included in the yield of condensibles.

Table 2.4 shows the net yields from experiment BP2-57 as compared to experiments conducted in inert gas and in $\mathrm{H}_{2} .{ }^{2}$ Yields of $\mathrm{H}_{2}, \mathrm{CO}$, and $\mathrm{CO}_{2}$ indicate that some steam gasification has occurred. Based on stoichiometric comparison of BP2-57 and the argon-purged experiment, $60 \%$ of the steam fed to the reactor was consumed by gasification ( $1.0 \%$ of the coal weight, maf) and char consumption was $0.7 \%$ of the maf coal weight. The other effect is that in BP2-57 and the $\mathrm{H}_{2}$ experiment, an additional $3 \%$ of $\mathrm{CH}_{4}$ was measured relative to the $\mathrm{Ar}$ experiment, possibly at the expense of char.

\subsubsection{Physical properties of coal}

Bulk properties of wet and dry coals are important to the accurate modeling of UCG. Most coal use traditiona1ly has been of bituminous and anthracite coal, both low in moisture content. As a result, the effect of moisture content on properties like density, thermal

diffusivity, and thermal conductivity has received 11ttle study. Lignite and subbituminous coal are of interest in UCC, and their typically high moisture contents make such effects important. In addition, the lowrank coals shrink as they dry with an irreversible collapse of the coal structure. 3

Density, shrinkage, and porosity data presented last month ${ }^{1}$ are analyzed further in Table 2.5. Note the $8-9 \%$ shrinkage in the lowrank coals, compared to no shrinkage in the bituminous coal. Also, bulk porosities of the three coals have been calculated. Because porosity of lignite particles only includes pores sized $3 \mu \mathrm{m}$ or smaller, 
Table 2.4. Comparison of yields from block pyrolysis of Pittsburgh bituminous coal. All experiments $3 \mathrm{~K} / \mathrm{min}$ to $1073 \mathrm{~K}$. Yields in $\mathrm{Ar}$ and $\mathrm{H}_{2}$ based on previous correlations (ref. 2).

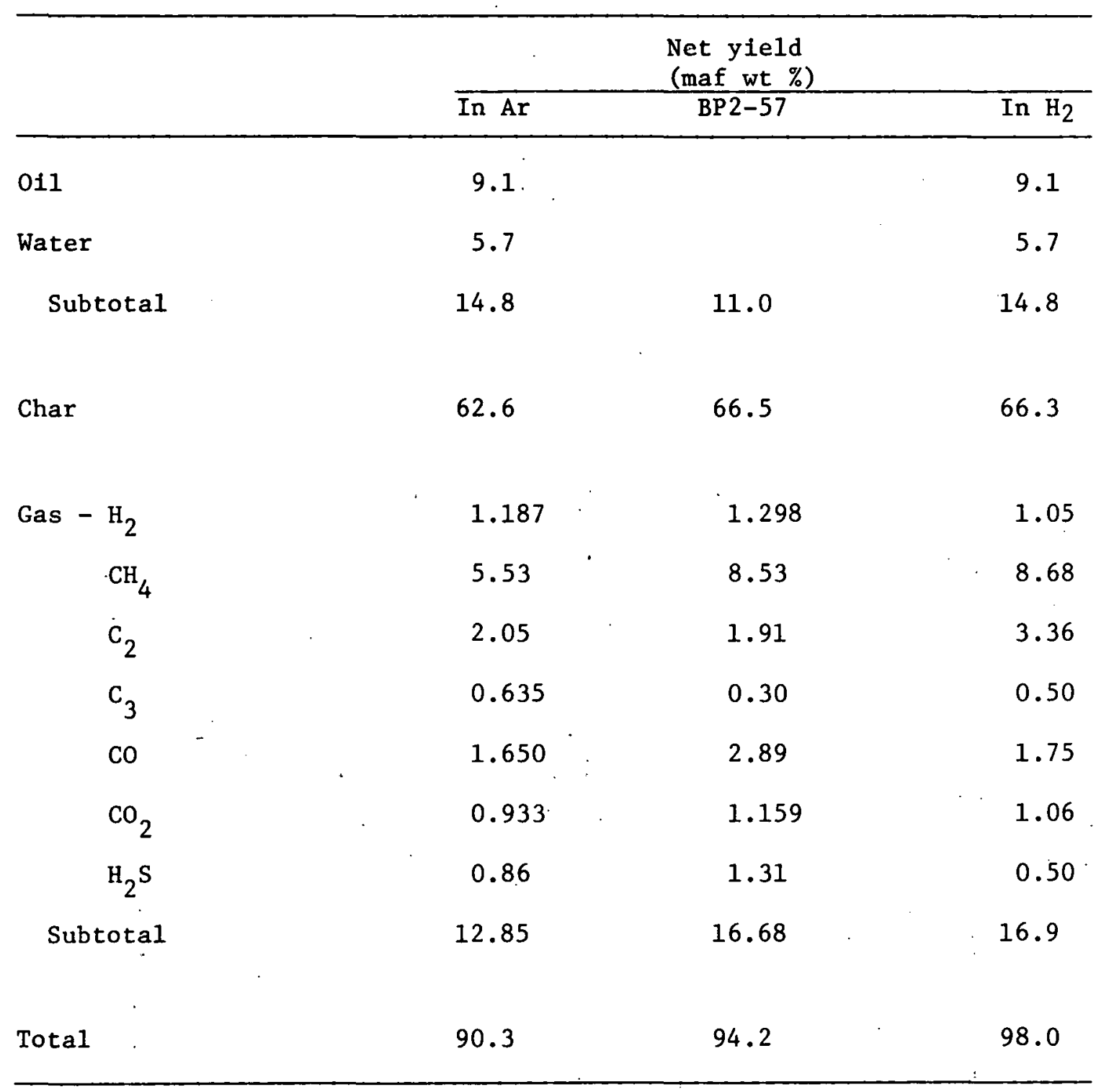


Table 2.5. Shrinkage, density and porosity measurenezts

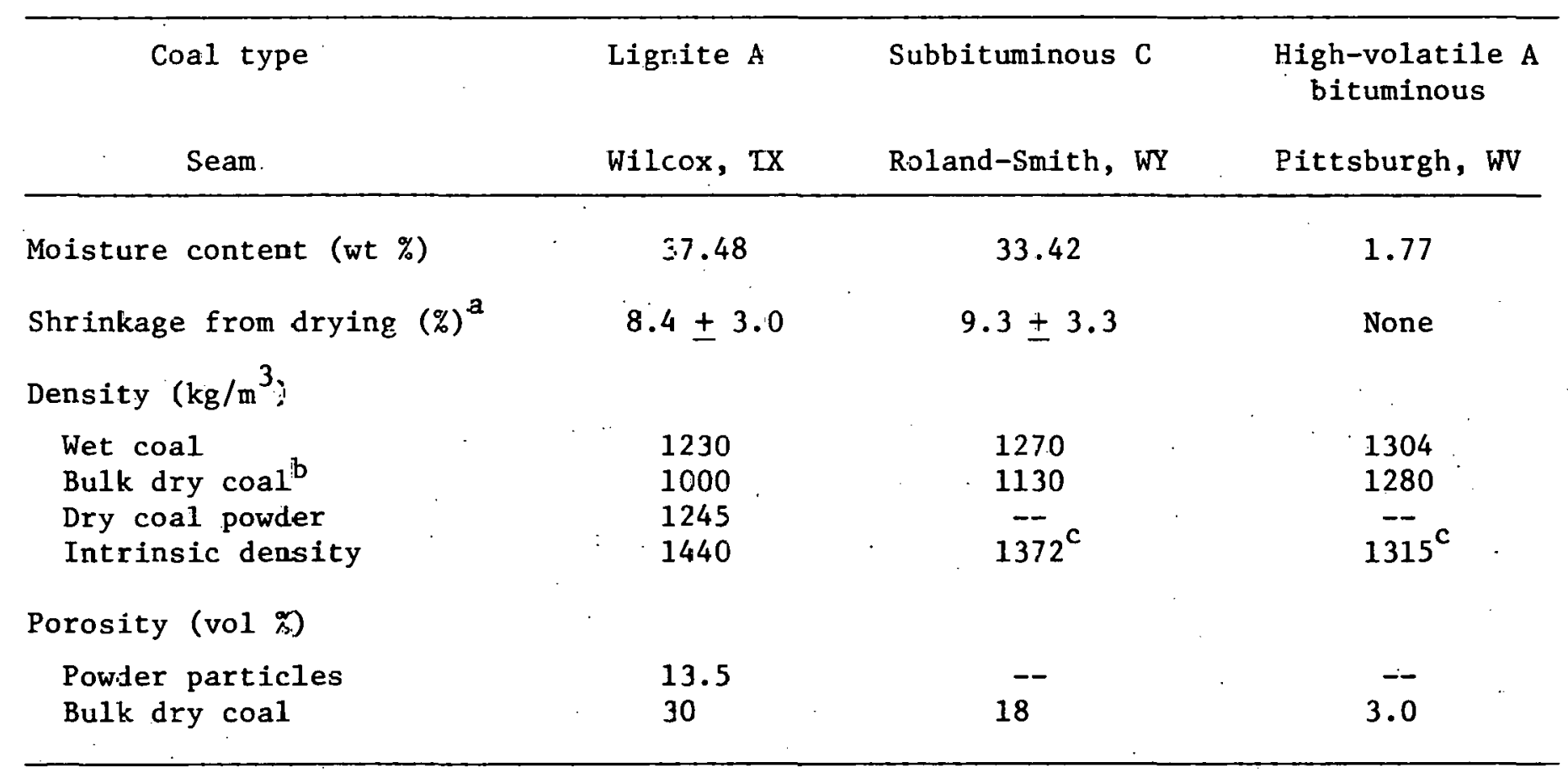

average linear shrinkage.

${ }^{b}$ Calculated by (wet density) x $\left(1\right.$ - moisture/100)/(1 - shrinkage/100) ${ }^{3}$.

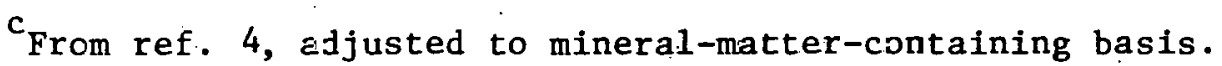


the higher porosity of bulk lignite reflects the large volume contained in cracks and very large pores, which are destroyed when the coal is ground to a powder.

Thermal conductivity of lignite, previously calculated in this research from measured thermal diffusivity, may be determined more accurately using the density measurements in Table 2.5. In Table 2.6 these thermal properties of lignite are compared to values measured before.2,5,6 Agreement with other values for lignite are quite satisfactory. Although models of UCG in low-rank coals have used thermal conductivity data from bituminous coal, such data may overestimate thermal conductivity of dry low-rank coal by $25 \%$ and underestimate it for wet low-rank coal by $90 \%$.

\section{5 .3 Future plans}

During the next reporting period, experiment BP2-58 will be conducted on Wilcox lignite using the same conditions as in BP2-57. Physical property measurement and correlation will continue and preparation of a project summary report will begin.

\subsection{References for Section 2}

1. L. E. McNeese (ed.), Fossil Energy Program Progress Report for March 1979, Oak Ridge National Laboratory, ORNL/TM-6886, May 1979.

2. L. E. McNeese (ed.), Fossil Energy Program Quarterly.Progress Report for the Period Ending September 30, 1978, Oak Ridge National Laboratory, ORNL-5487, January 1979, pp. 50-82.

3. M. L. Gorbaty, Fuel, 57, No. 12, December 1978, pp. 796-7.

4. H. Gan, S. Nandi, and P. L. Walker, Fuel, 51, No. 4, October 1972, pp. 272-277.

5. W. Fritz, Forschung auf dem Gebiete des Ingenieurwesens, 14, No. 1, 1943, pp. 1-10.

6. B. R. Stanmore and A. R. Boyd, 2nd Australasian Conference on Heat and Mass Transfer, University of Sydney, 1977, pp. 115-120; cited in C. Karr (ed.), Analytical Methods for Coal and Coal Products, Vol. 1, Academic Press, New York, 1978, p. 97. 
Tajle 2.E. Thermal diffusivizy and thermal conductivity of coal

\begin{tabular}{|c|c|c|c|c|}
\hline Coal rank & $\begin{array}{l}\text { Source } \\
\text { (ref.) }\end{array}$ & $\begin{array}{l}\text { Thermal diffusivity, } \\
\left(\mathrm{mm}^{2} / \mathrm{sec}\right)\end{array}$ & $\begin{array}{l}\text { Thermal conductivity, } \\
(\mathrm{W} / \mathrm{m} \cdot \mathrm{K})\end{array}$ & Comments \\
\hline Lignite (dry) & This work & 0.09 & 0.14 & $410-570 \mathrm{~K}, 30 \%$ porosity \\
\hline$(d r \nabla)$ & 5 & -- & 0.151 & $303 \mathrm{~K}, 32 \%$ porosity \\
\hline (wet) & This work & 0.16 & 0.37 & $37 \%$ moisture \\
\hline (wet) & 6 & 0.142 & -- & Bed-moist \\
\hline Subbituminous (dry) & & -- & $0.15-0.19$ & $298-363 \mathrm{~K}$ \\
\hline Bituminous $(\mathrm{dry})$ & 1 & -- & $0.17-0.26$ & $298-673 \mathrm{~K}, 36 \mathrm{coals}$ \\
\hline Anthracite (dry) & 1 & -- & $0.19-0.34$ & $287-673 \mathrm{~K}, 17$ coals \\
\hline
\end{tabular}




\title{
3. CHEMICAL RESEARCH AND DEVELOPMENT
}

\author{
M. L. Poutsma
}

\subsection{Chemistry and Structure of Coal}

\author{
M. L. Poutsma
}

This month we have gathered further information concerning the pyrolysis of pure bibenzyl, and we have begun studies of the perturbing effects of phenol on this pyrolysis. Since the exploratory phase of the latter topic is still in progress, we will defer reporting until next month and will concentrate here on the former.

The identities of products $\underline{\underline{4}}$ and $\underline{\underline{5}}$ has been confirmed by results of gc-ms as well as $\mathrm{nmr}$ of fractions from. preparative gc of a pyrolysis run of liquid 1 at $400 \pm 1^{\circ} \mathrm{C}$ for $143 \mathrm{~min}$ ( $10 \%$ conversion). The meso: $\mathrm{d} 1$ ratio for $\underline{\underline{5}}$ was found to be $1: 1$; hence there is no stereoselectivity in the radical coupling process which gives 5 . A second preparative run was carried out at $398 \pm 1^{\circ} \mathrm{C}$ for $20 \mathrm{hr}(7 \overline{\overline{5}} \%$ conversion). Preparative gc gave

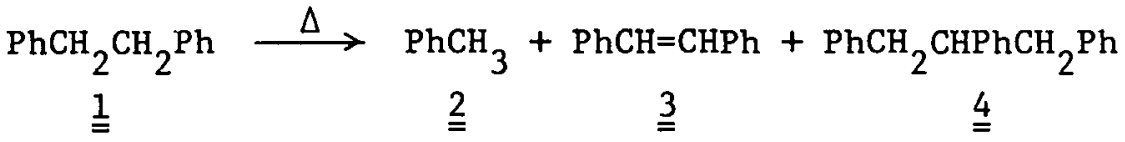

$$
\begin{aligned}
& +\mathrm{PhCH}_{2} \mathrm{CHPhCHPhCH}_{2} \mathrm{Ph} \\
& \underline{5}
\end{aligned}
$$

a sample of trans-3 whose nmr spectrum demonstrated the absence of the cis isomer and of 9,10 -dihydrophenanthrene, which has the same retention time as 3. Samples of the three major secondary products which accumulate in high-conversion runs were shown by nmr to be 1,1-diphenylethane ( $\underline{\overline{8}})$, diphenylmethane $(\underline{\underline{9}})$, and phenanthrene $(\underline{\underline{10}})$. This work then complètes the

$$
\begin{array}{cc}
\mathrm{Ph}_{2} \mathrm{CHCH}_{3} & \mathrm{Ph}_{2} \mathrm{CH}_{2} \\
8 & 9
\end{array}
$$

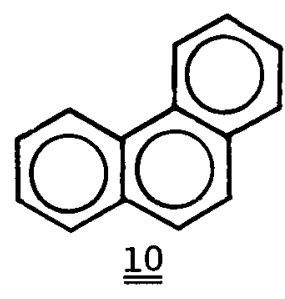

rigorous structural assignment for all significant primary and secondary pyrolysis products of $\underline{\underline{1}}$ at $\sim 400^{\circ} \mathrm{C}$ as detected by gc analysis.

Results to date have not eliminated the possibility of a primary product even less volatile than $\underset{=}{5}$. Therefore, a sample of liquid 1 was pyrolyzed at $401 \pm 1^{\circ}$ for $143 \mathrm{~min}$ ( $9.9 \%$ conversion) and the majority of the residual $\stackrel{1}{\underline{1}}$ was removed by sublimation to concentrate the least 
volatile products. Comparison of its weight with its gc analysis with our usual internal standard showed that the sum of $\underline{\underline{1}}, \underline{3}, \underline{4}, \underline{\underline{5}}, \underline{8}$, $\underline{9}$, and other trace materials accounted for $96 \%$ of the products. Hence no significant heavy product has been missed.

Earlier we demonstrated that primary products $\underline{\underline{4}}$ and $\underline{5}$ are thermally more labile than 1 . Although the rates and product $\overline{\bar{s}}$ of décomposition as neat materials would not be expected to be identical with those in the presence of an excess of 1 because of hydrogen atom transfer reactions, nevertheless it seemed worthwhile to pyrolyze $\underline{4}$ and $\underline{5}$ individually. Pyrolysis of 4 at $400 \pm 2{ }^{\circ} \mathrm{C}$ for 115 min gave $9 \overline{9} \%$ decomposition (under these conditions, the conversion of 1 was $11.4 \%$ ); the major products in order of importance were $2,3,1$, and an unknown of retention time slightly longer than 4 . Parallel treatment of meso-5 gave $99.7 \%$.conversion mainly to form $3,2, \overline{\overline{1}}$, and 4 in order of decreasing molar amounts. Hence it is clear that 4 an $\underline{\bar{d}}$ do $\overline{\bar{d}}$ ecompose largely by $\mathrm{C}-\mathrm{C}$ homolysis into the same radical network outlined last month.

Last month we alluded to still another possible primary product appearing only at very low conversions. This has turned out to be an impurity in one particular batch of starting 1 .

\subsection{Kölbe1 Process Concepts}

M. L. Poutsma

At the request of DOE Fossil Energy, Division of Planning and Systems Engineering, a 12-week chemical assessment of K̈ölbel process concepts and their impact on advanced processes for indirect liquefaction has begun. Literature background on the Kölbel slurry reactor, the Kölbel-Engelhardt reaction, and the feed flexibility for the M-Gasoline process is being àssemuled and correlated. 


\title{
4. MATERIALS ENGINEERING
}

\author{
R. A. Bradley
}

The materials engineering and associated technology reported here are in support of activities directed or coordinated by the Materials Engineering Branch, Division of Systems Engineering, Fossil Energy. Other related work funded by the Division of Fossil Fuel Utilization and the Division of Fossil Fuel Processing is also included.

\subsection{Pressure Vessel and Piping Materials}

W. J. Stelzman, R. O. Williams, and D. A. Canonico

The objective of this task is to determine the fracture toughness of pressure vessel steels and to study their susceptibility to hydrogen attack. The characterization of $21 / 4 \mathrm{Cr}-1$ Mo steel given various heat treatments to simulate the properties of thick sections is continuing. We have completed tensile and Charpy testing of specimens from bars that were slow cooled $(0.3 \mathrm{~K} / \mathrm{s})$ from $1038^{\circ} \mathrm{C}\left(Q_{S}\right)$, tempered at $704^{\circ} \mathrm{C}(\mathrm{T})$, stress relieved for $40 \mathrm{~h}$ at $677^{\circ} \mathrm{C}[\mathrm{SR}(40 \mathrm{~h})]$, and aged for $1000 \mathrm{~h}$ at $343^{\circ} \mathrm{C}[\mathrm{A}(1000 \mathrm{~h})]$. Neither the tensile nor Charpy results for these aged specimens differ significantly from the results previously obtained with the $40-h$ stress relief $\left[Q_{S}+T+\right.$ SR $(40 \mathrm{~h})]$. We also completed the Charpy testing of tempered, stress-relieved, and aged specimens from bars fast cooled $(3 \mathrm{~K} / \mathrm{s})$ from $1038^{\circ} \mathrm{C}\left[\mathrm{Q}_{\mathrm{F}}+\mathrm{T}+\right.$ $\mathrm{SR}(40 \mathrm{~h})+\mathrm{A}(1000 \mathrm{~h})]$. Aging for $1000 \mathrm{~h}$ at $343^{\circ} \mathrm{C}$ improved the notch toughness of the $Q_{F}+T+S R(40 \mathrm{~h})$ material. Results from a limited number of specimens shows a decrease in the $41 \mathrm{~J}$ transition temperature and an increase in the upper shelf energy from $116 \mathrm{~J}$ to $136 \mathrm{~J}$. We are also precracking Charpy bars and will resume the static fracture toughness testing in the near future.

The study of the influence of hydrogen-rich environments on candidate steels for coal conversion pressure vessels and piping is continuing. Various problems have prevented the successful completion of the run designed to investigate the effect of microstructure on the susceptibility to hydrogen attack. The convection currents in the hydrogen inside the autoclave remain a problem. Metal baffles will be installed to reduce this effect. Work has been initiated on upgrading the thermodynamic computer program for predicting the Nelson curves by replacing the present set of parameters with the new set being generated by L. Kaufman and coworkers. 1

\subsection{Fossil Energy Welding and Cladding Development \\ D. P. Edmonds and J. F. King}

Negotiations are continuing with commercial manufacturers to develop cladding techniques for type 320 stainless steel using the submerged-arc strip cladding process. Strip intentionally fortified with nickel will be used to produce overlay clad specimens for characterization at ORNL. 
A review of the Fossil Energy Materials Programs, including the Welding and Cladding Program, was held at DOE in Germantown on April 24, 1979.

A final draft of the report entitled Cladding of $21 / 4 \mathrm{Cr}-1$ Mo Steels With Type $320 \mathrm{Cb}$ Stainless Steel has been completed and submitted for technical editing and review.

\subsection{Fireside Corrosion of AFBC Tubes}

T. G. Godfrey and J. H. DeVan

Examination of tube samples from the 4500-h experiment in the Fluidyne atmospheric fluidized-bed combustor ( $A F B C$ ) is continuing. The remaining tive of the sixteen high-temperature tubes have been submitted for preparation of metallographic specimens. When the examination of these tubes is complece, 39 of the 41 tubes exposed in the AFBC during the series of tests totalling $4500 \mathrm{~h}$ will have been examined. Hopefully, these last samples will provide some insight into the cause of the sulfidation corrosion of tube $9 \mathrm{~B}$ and the time during the final $3000-\mathrm{h}$ portion of the test when it occurred.

\subsection{Failure Prevention and Analysis}

R. W. Swindeman

\subsubsection{Examination of corrosion coupons from solvent-refined coal plants}

(V. B. Baylor, J. R. Keiser, R. S. Crouse, and M. D. Allen)

The draft of the report on the analysis of the first two sets of corrosion coupons from the Wilsonville solvent-refined coal (SRC) pilot plant has been reviewed by Catalytic, Inc., personnel at Wilsonville and Philadelphia. Comments will be incorporated for internal review of this document.

The third set of coupons from the Wilsonville dissolver was examined for stress-corrosion cracking, as requested by Air Products, Inc. The coupons were found to be free of cracks except for the RA 330 specimen where small cracks were noted extending from the weld into the heataffected zone (HAZ). These cracks are associated with welding and not stress corrosion. The scale characteristics were similar to those observed after previous exposures.

The microprobe analyses of the coupons from the Fort Lewis SRC pilot plant is still proceeding. A report will be drafted as soon as all analyses are complete.

Racks of unstressed specimens are being readied for insertion into the fractionation column at Wilsonville. Besides the materials already on hand for stress-corrosion cracking studies, other materials received for this task include Nitronic 50, Sandvik 2RE69, Hastelloy G-3, Haynes 20 Modified and NYBY Monit. 
4.4.2 Examination of failed T105 fractionation column at the Wilsonville SRC plant (B. C. Leslie, V. B. Baylor, J. R. Keiser, and M. D. Allen)

Metallographic examination of vessel walls and internals showed the corrosion attack to be intergranular. Inspection revealed the column to be more damaged than first presumed, with the type 304 stainless steel liner no longer able to provide protection to the mild steel vessel walls. Intergranular attack was observed perpendicular to weldments as well as in weldments; random selection of areas to be examined showed no unattacked regions. Laboratory examination is continuing.

The Wilsonville plant operators have decided to replace the internals with type 321 stainless steel. This decision was based on material availability and not corrosion resistance. The column will not be relined; however, the type 304 stainless steel cladding will be extended upwards from its present halfway level.

\subsection{Materials for $\mathrm{ZnCl}_{2}$ Liquefaction Process \\ J. R. Keiser and V. B. Baylor}

The design for the quartz loop testing apparatus is complete and will be delivered to the glass shop for their recommendations on suggested modifications from a fabricability standpoint. The heaters and other supplementary equipment are being ordered.

\subsection{Materials to Resist Stress-Corrosion Cracking in Coal Liquefaction Pilot Plants}

J. R. Keiser and V. B. Baylor

The U-bend specimens exposed at the Fort Lewis SRC plant have been measured, weighed, and evaluated in the laboratory and are being examined metallographically. Springback measurements showed that a considerable amount of stress was still present in the specimens after exposure, and stress relaxation at high temperatures may not be a problem. Fifty specimens at Fort Lewis and thirty specimens at the Wilsonville SRC plant are still in test and are expected to be removed this summer.

Rearrangement of the laboratory to accommodate test equipment is continuing. Tentative approvals to proceed have been obtained from the Metals and Ceramics Division Hydrogen Committee and ORNL Industrial Hygiene Department. Approval must still be obtained from the High-Pressure Experiment Review Committee before testing can begin. 


\subsection{Development of Advanced $9 \mathrm{Cr}-1$ Mo Structural Steel}

V. K. Sikka

Mechanical property characterization, fabrication, weldability, and steam corrosion studies continued on the experimental heats and two of the four DOE Reactor Research and Technology Division commercial argon-oxygendeoxidization (AOD) process heats. Several accomplishments made during the last month are as follows:

1. Charpy specimens were prepared from the weld and heat-affected zone (HAZ) of the gas tungsten-arc welded plate from the Quaker heat. Testing of these specimens will be initiated during the next month.

2. Four creep ruptures occurred in tho baoc metal specimens and three in the welded plate. The welded specimens are showing reduction of area values of about $90 \%$, but are weaker hy at least an order of magnitude in time to rupture as compared to the base metal curve. The lower creep rupture values are due to the fact that the first weld was made with unmodified commercial $9 \mathrm{Cr}-1$ Mo weld metal (which is free from the crecp strengthening elements columbium and vanadium). Based on the data available thus far, the next weld will be made using the weld wire made from the modified $9 \mathrm{Cr}-1$ Mo base metal. Several postweld heat treatments will also be tried on the welds to be made during the next month.

3. Steam corrosion specimens were removed after about $20,000 \mathrm{~h}$ exposure in steam at 482 and $538^{\circ} \mathrm{C}\left(900\right.$ and $\left.1000^{\circ} \mathrm{F}\right)$. Scale thickness on modified $9 \mathrm{Cr}-1$ Mo is comparable to $21 / 4 \mathrm{Cr}-1$ Mo ste.e 1 hut slight ly thicker than the commercial unmodified $9 \mathrm{Cr}-1$ Mo alloy. The reason for the latter is the high silicon content $(0.45 \%)$ in the commercial material as opposed to only $0.10 \%$ silicon content in the modified heats. Experimental heats containing varying amounts of silicon are currently being melted to establish limits on this element for optimum corrosion and mechanical properties.

We are still waiting on the bids for the large heats from various steel mills.

\subsection{Ceramic Recuperators (Heat Exchangers)}

V. J. Tennery. G. W. Weber, and G. r., Wei

As reported in the previous monthly, discussions with Hague International of South Portland, Maine, resulted in an effort to issue a subcontract to evaluate the suitability of silicon carbide heat exchangers lor foss1l-fired applications. A proposed work statement for exposure to coal-oil mixture combustion products at representative use temperatures and flows with accompanying permeability and leakage testing was received from Hague International. The proposal from Hague has been evaluated and suitable tasks have been identified. The subcontract is anticipated to be established during the next month. 
The subcontract with Garrett-AiResearch (Torrance, California) to develop preliminary designs for ceramic heat exchangers is nearly complete. These designs, encompassing requirements of the steel, aluminum, and glass industries, are anticipated to be completed within the next month.

The modification to the refractories test facility to permit evaluation of ceramic heat exchanger materials is proceeding on schedule. Bidding has been completed and a contractor has been identified to fabricate the unit's shell with a delivery time of six weeks after receipt of order. A subcontractor has also been identified for placing the castable refractory lining in the unit. Fabrication of tube supporting blocks has been initiated. Metal forms have been constructed, and casting and curing techniques have been identified. Drying and firing of these components are in progress.

Measuring equipment to support the testing has also been identified. A radiation-shielded suction pyrometer has been ordered with a matching digital thermocouple readout apparatus. Multipoint recorders have been obtained and refurbished and thermocouples and compensation wires ordered. Air flow and pressure measuring devices have been acquired. A permeability testing apparatus has been received from AiResearch and is being connected to a helium leak detector and flow control panel. A mechanical testing procedure (half-ring compression) has been established. Analytical chemistry techniques have been defined for both condensable and noncondensable gases.

\subsection{References}

1. L. Kaufman, "Coupled Phase Diagrams and Thermochemical Data for Transition Metal Binary System - VI," Calphad 3: 45 (1979). 


\section{COAL EQUIPMENT TEST PROGRAM}

J. M. Holmes and R. E. MacPherson

Work under the Coal Equipment Test Program (CETP) is currently divided into four sections:

- Coal Feeder Test Program

- Survey of Industrial Capability for Coal Handling Equipment

- Support for the Solvent Refined Coal Project

\subsection{Coal Feeder Test Program \\ B. T. Thempenn and A. R. Sadlowe}

Results of the feasibility study and planning cost estimate for the Dry Coal Handling/Feeding Test Facility were presented to program personnel at the Morgantown Energy Technology Center. Editing is complete on the report which should be issued in May. The report has generally been well received, and examination of potential sites will be started.

\subsection{Survey of Industrial Capabil.ity for \\ Coal Handling Equipment}

F. C. Zapp, O. W. Thomas, M.D. Silverman, D. A. Dyslin

Approximately half of the equipment survey report has been completed as a rough draft. Included in this rough draft are sections on survey results for the various types of equipment, conclusions and recommentations, and appendices containing questionnaire forms used. The report is being typed on word processing equipment to facilitate changes.

Bechtel National plans to complete a rough draft of their report by May 8. Information from the Bechtel report is needed to rnmplete the ORNL répórt.

\subsection{Support for the Solvent Refined Coal Project}

F. K. Carlsun, L. F. Paraly, J. M. llolmes

As part of the SRC Demonstration Plants Project R\&D Support Task, visits were made to the Exxon Donor Solvent experimental facilities at Baytown, Texas, and the Solvent Refined Coa1 Pilot Plant at Wileonvillc, Alabama, to learn of their experience with pumps, compressors, valves, and instruments. Additional information on valves was obtained by phone from the Willis 0il Tool Co. who believes they can supply valves capable of handling the severe conditions of high temperature and high pressure associated with slurry handling in SRC plants. This prediction is based on successful experience gained in HYGAS plant service, with results to 
be published in an article in "Plant Engineering". Our contribution to the Phase II report under this task is being written and will be completed about the middle of May. 


\title{
6. ENGINEERING STUDIES AND TECHNICAL SUPPORT
}

\author{
R. W. Glass
}

Engineering studies and technical support are provided primarily for the DOE/FE Division of Fossil Fuel Processing. The effort includes: the development of analytical tools for use in the evaluation of processes and equipment; the technical and economic evaluation and comparison of coal conversion processes and subprocesses on a uniform basis; surveys of the need for coal conversion equipment and the capability of industry to provide such equipment; and studies of the magnitude and control of coal conversion plant emissions.

\section{1 Process Modeling}

R. Salmon, D. M. Lister, O. L. Culberson, D. G. Ball, K. W. Childs.

\subsubsection{Contract Ubjective}

The objective is to assist DOE/FE in its plan for computer analysis and computer support for coal conversion studies. This includes assistance to Purdue and Lehigh Universities in the development of computer programs for this plan. Physical property data are being collected and computerized primarily by Purdue and will be used in support of programs prepared by both universities. Purdue's general design program will aim at material and energy balances, equipment size and costing, plant capacity, and general economics. Lehigh's dynamic simulation programs will address plant design primarily from the standpoint of process performance during transient operations, but can also be used for steady-state conditions. A single flowsheet will be selected to assess the operability and complementary utility of both design programs.

\section{1 .2 Status Summary}

Purdue Physical Properties Package (PPROPS): The IBM version of PPROPS, complete with test examples furnished by Purdue and results of these examples, was loaded onto magnetic tape and forwarded to James Mercer at DOE, Morgantown. He has since acknowledged receipt of the package and advised us that all test cases executed successfully on their IBM computer.

An effort is being made to run additional PPROPS examples based on a simple process flowsheet devised by ORNL. Comparisons are being made with results from the Phillips PDA program. Thus far, the PPROPS results have not been satisfactory. The subroutine LOADP has been rewritten and is currently being tested. A summary of this work is being prepared in an effort to resolve these difficulties with Purdue. 
Lehigh DSS/2 Program: Testing of the latest double precision version of DSS/2 obtained from DPCON-1 and the documentation of DPCON-1 continued during the reporting period.

Receipt of Additional Codes from Purdue and Lehigh: No further codes or documentation have been received during the reporting period.

\subsection{Coal Liquefaction Advanced Research Digest}

F. M. O'Hara, Jr., and R. W. Glass

\subsubsection{Contract Objective}

The objective is to provide continuing technical assistance to DOE/FE by preparing digest reviews of current or potential subjects relating to coal conversion technology.

\subsubsection{Status Summary}

Discussions with DOE/FE during this reporting period narrowed the subject matter of the fourth issue of the Digest to three topics. Preliminary searches of the current research in those subject areas were performed, and précis of that work were prepared and forwarded to DOE/FE. Comments on and approval of those three topics were then sent back to us.

The three'titles chosen for inclusion are "Coal Depolymerization," "Free Radical Chemistry of Coal Liquefaction," and "Inherent Catalysis of Coal." Work began on the researching and writing of the first of these, and the summary of that topic follows:

\section{Coal Depolymerization}

Coal depolymerization is being studied both as an end in itself and as an analytical tool.

As an end in itself, depolymerization breaks coal down through dissolution and chemical attack to desirable components (relatively low-molecular-weight liquid or gaseous hydrocarbons) or to feedstocks for the production of such desirable materials. This is the basis of much of the chemistry of the CSF process, the Exxon Donor Solvent process, the SRC processes, and other processes employing coal dissolution. 
As an analytical tool, depolymerization is being used by Larsen at the Oak Ridge National Lab. and by Morrey and Tingey at Battelle Northwest to cleave linkages among the macromolecular structures of coal. Once this is done, the aromatic clusters that are found in coal and the important functional groups (especially the heteroatom structures) can be identified and studied. The next step will be to use that knowledge of structure and depolymerization routes to identify scissile bonds cleaved during coal conversion so that better means of attacking those bonds can be devised.

\subsection{Survey of Industrial Coal Conversion Equipment Capabilities}

W. R. W1111ams, D. W. Haccher, J. R. Horton

\subsubsection{Contract Objective}

The objective of this project is to conduct surveys of industrial equipment availability that will identify the present capability of industry to supply the equipment needed. The project will also determine research and development needs, including lead time requirements, for producing equipment of advanced design for the various unit operations of critical importance to the Division of Fossil Fuel Processing.

\subsubsection{Status Summary}

The draft of the executive summary was completed during April. Both the executive summary and the report on equipment operating experience, prices, and development programs should be ready for DOE's review by late May. The report on mechanical piping connectors and expansion joints (ORNL/TM-6586) is to be published and distributed in May. The letdown valve report review will be completed in May.

The paper, "Department of Energy Fossil Energy Equipment Development Programs," was presented at the 86th National Meeting of AIChE in Houston, Texas, on April 4 by W. R. Williams. This paper was primarily based on findings of the industrial survey.

The study of pumping system costs has been extended to lower pressures. (The study was initially based on a discharge pressure of 2215 psia). Reciprocating pumps were found to retain their economic advantage over centrifugal pumps, irrespective of the assumed state of technology, to pressures as low as 600 psi. This conclusion lends economic justification to last year's recommendation: "Multistage centrifugal slurry pumps..need to be developed for heads as high as 600 to 800 psi...to bridge the gap between single-stage centrifugal pumps and reciprocating units." 1

Two committees have been appointed by L. E. McNeese, ORNL Fossil Energy Program Director, for the purpose of organizing and implementing the workshop on critical coal conversion equipment. A revised sumnary of the workshop has been prepared for transmittal to T. K. Lau, DOE/FFPWashington. This summary will form a basis for funding of the workshop. 


\subsection{Environmental Controls for Low-Btu Gasification}

S. P. N. Singh, M. S. Edwards, J. F. Fisher,

G. R. Peterson, and R. Salmon

\subsubsection{Contract Objective}

The objective of this project is to evaluate the various environmental control processes that might be used in connection with low-Btu gasification facilities and to determine the economic tradeoffs for various processes and levels of control.

The project is divided into two phases: Phase I consists of Tasks 1 through 5 of the work statement, and covers the preparation of a detailed work plan and the selection of gasification and environmental control processes for use in the study. Phase II consists of Tasks 6 through 8 in the work statement, and covers the collection and analysis of technical and economic data on the various environmental control processes and the preparation and analysis of flowsheets showing overall systems of environmental control processes used with various gasifiers.

\subsubsection{Status Summary}

DOE/Fossil Energy approval on the two draft reports titled Costs of Environmental Control Processes for Low-Btu Coal Gasification Plants (ORNL-5425), and Evaluation of Eight Environmental Control Systems for Low-Btu Coal Gasification Plants (ORNL-5481) has been received.

Copies of these reports have been distributed for proponent review. In-house editing will take place concurrently and issuance of the final reports is expected in July.

\subsection{SRC R\&D Assessment}

M. S. Edwards, B. R. Rodgers, C. H. Brown, P. K. Carlsul, W. R. Gambill, T. M. Gilliam, J. M. Holmes, R. P. Krishnan, L. F. Parsly

\subsubsection{Contract Objective}

This project is an intensive, short-term assessment of current research and development activities of importance to the SRC Demonstration Project. The assessment includes acquisition and review of published information, discussions with R\&D personnel involved in relevant activities, visits to sites of important R\&D activities, monitoring of critical R\&D operations, accessing, to the extent possible, the proprietary information of importance to the Project, and cross-matching R\&D activities to the technical data needs of the industrial partners in the 
Demonstration Project. Based on the assessment of R\&D activities against the data needs of the SRC Demonstration Project, recommendations will be formulated, including: priority of activities; adequacy of the R\&D program; the need for possible acceleration, extension, or redirection of current activities; and possible new activities required beyond the current program.

\section{5 .2 Status Summary}

Team members have been contacting and visiting institutions working in areas related to the R\&D problems identified in the Phase I Report (submitted to DOE/Oak Ridge Operations in February, 1979). These contacts serve to determine the status of current and planned activities which have a potcntial impacl Uil Lle SRC Demonstration Plants designs. By. comparing the current and planned activities with the R\&D data needs of the SRC designers, OKNL will be able to develop recommendations to the SRC Demonstration Plants Project of what additional activities are justified in support of the Demo designs. These recommendations will be provided in the Interim Phase Report, draft scheduled for June 1, 1979.. The format and content of the Interim Phase Report are evolving through discussions with the Assessment Program Manager, J. A. Reafsnyder.

Trips in April are shown in Table 6.5.1, keyed to the problem areas discussed. About 6 to 8 remaining institutions will be visited in May, excluding the three major installations of principal importance to the SRC R\&D assessment. These three are the Ft. Lewis SRC pilot plant, the Gulf Harmarville PDU, and the Texaco Gasification pilot plant. Arrangements for visiting these installations are being pursued by DOE/ORO. The other trips include three universities, one or more energy technology centers, a national laboratory, and the Wilsonville SRC pilot plant.

\subsection{Fuel-Grade Methanol Synthesis Technology Assessment}

R. Salmon, M. S. Edwards, R. M. Wham

\subsubsection{Contract Objective}

The objective of this work is to review and assess the present state-of-the-art of indirect liquid fuels synthesis, with particular emphasls placed upon those processes which produce methanol suitable for use as fuel as the primary or principal product.

\section{6 .2 Status Summary}

Information on currently commercial methanol synthesis processes, ICI, Lurgi, Haldor Topsoe and Mitsubishi Gas-Chemical, has been obtained through vendor contacts, discussions and a literature survey. Details on previously commercial technologies and concepts have been obtained from the literature, e.g., by a patent search. Developing processes for 
Table 6.5.1. SRC R\&D assessment trips in April 1979

\begin{tabular}{|c|c|}
\hline Problem area & Institutions \\
\hline General Iiquefaction & Exxon EDS, Baytown \\
\hline Fired heater & Heat Research Corp. \\
\hline Vapor-liquid separations & Rice University (Kobayashi) \\
\hline Solid-liquid separations & University of Houston (Tiller) \\
\hline $\begin{array}{l}\text { Fired heaters, physical } \\
\text { properties }\end{array}$ & $\begin{array}{l}\text { Argonne National Laboratory } \\
\text { (Mulcahey) }\end{array}$ \\
\hline $\begin{array}{l}\text { General liquefaction, } \\
\text { gasification R\&D }\end{array}$ & EPRI (Ron Wolk) \\
\hline $\begin{array}{l}\text { Fired heaters, physical } \\
\text { property correlations }\end{array}$ & IGT (Talwalker) \\
\hline Vapor-1iquid separations & $\begin{array}{l}\text { University of California, } \\
\text { Berkeley (Prausnitz) }\end{array}$ \\
\hline Solid-iiquid separation & $\begin{array}{l}\text { Illinois Institute of Tech- } \\
\text { nology (Gidaspow) }\end{array}$ \\
\hline $\begin{array}{l}\text { Coal liquefaction kinetics, } \\
\text { erosion studies }\end{array}$ & $\begin{array}{l}\text { Lawrence Berkeley Laboratory } \\
\text { (Vermullen, Levy) }\end{array}$ \\
\hline Heat exchangers & Heat Transfer Research Institute \\
\hline Coal 1iquefaction kinetics & $\begin{array}{l}\text { Stanford Research Institute } \\
\text { (Ross, Golden) }\end{array}$ \\
\hline Asphaltenes characterizations & $\begin{array}{l}\text { University of Southern California } \\
\text { (Yen) }\end{array}$ \\
\hline Fired heater & Kinetics Technology, Inc. (Bloomfield) \\
\hline Solid-liquid separation & Johns-Manville (Smith) \\
\hline $\begin{array}{l}\text { Coal liquefaction kinetics, } \\
\text { mechanisms, enthalpy }\end{array}$ & Colorado School of Mines (Kidnay) \\
\hline Solid-liquid separation & University of Michigan (Briggs) \\
\hline
\end{tabular}


methanol synthesis are being investigated through acquisition of published information and discussions with the developers, i.e., the Chem Systems three-phase reactor process and the Wentworth Brothers Methyl Fuel process.

Information on these processes and any others identified will be reviewed in the next month. A judgmental assessment of relative technical and economic potential of the identified processes, relative to production of fuel-grade methanol, will then be performed.

\subsection{Liquefaction Techinology Assessment Study (LTAS)}

R. C, Forrester TtT, R. Salmon, M, S. Edwards, A. R. Irvine, S. P. N. Singh, J. F. Fisher, J. P. Meyer, R. M. Wham

\subsubsection{Contract Objective}

The objective of this study is to provide a comparative assessment of the technical feasibility, economic competitiveness, and environmental acceptability of selected coal liquefaction processes representing different process classes on a uniform, consistent, and impartial basis.

This assessment encompasses four phases of work, identified as Phase 0, Phase I, Phase II, and Phase III. Each phase includes development of process designs, capital and operating cost estimates, process economic analysis, sensitivity studies, and assessment of technical feasibility and risk on as consistent a basis as possibie. Existing process designs and cost estimates will be used whenever possible, with modification as necessary.

\section{7 .2 Status Summary}

Phase 0 activities are well underway with the identification of available process designs for use in the preliminary technology assessment. Process descriptions, flowsheets, and design bases are being prepared (with references) for the following processes:

Exxon Donor Solvent (EDS)

First generation methanol synthesis - followed by conversion to gasoline using the Mobil-M process

Flaeh hydropyrolysis

$\mathrm{ZnCl}_{2}$ process

Advanced hydrocarbonization

Advanced Fischer-Tropsch 
Pyrolysis followed by advanced Fischer-Tropsch

Supercritical extraction - followed by indirect liquefaction of solid residues

Disposable catalyst process

Fischer-Tropsch with upgrading of oxygenates

The general basis for design to be followed is given in the following paragraphs.

\section{Basis for Design}

\section{a. Feed Coal Selection}

The study of each liquefaction process shall be carried out using two coals:

1. Generic Illinois No. 6

2. Generic Montana subbituminous

Since these coals represent two distinct areas of the United States with respect to availability of water, designs utilizing subbituminous coal should minimize water consumption through use of air cooling, where practical. In those cases where the use of one coal or another is clearly impractical, process designs based on that coal should be omitted. In Phase 0 , each process may be limited to one coal type.

\section{b. Siting and Capacity}

The plant designs shall be based on a nominal process capacity of 30,000 TPSD (moisture- and ash-free basis) of prepared coal and the plants shall be located at a generic mine-mouth site on the Ohio River or in a semi-arid Western location, depending upon the feed coal being utilized. The mine shall not be a part of the plant base design but may be a captive mine selling coal to the plant on a long term contract.

\section{c. Plant Scope}

The plants shall produce no net power or char for sale. Purchased power may be allowed for small plant loads but not for major plant drive systems. To the extent reasonably possible the plants shall be self-sufficient except for coal, water, chemicals and catalysts, and small amounts of purchased power. For consistency, it is preferable to have all plants generate $100 \%$ of their steam and power requirements, including emergency loads. 


\section{d. Environmental Constraints}

Environmental standards shall be projected for the year 1995 both for the coal conversion plant and its effluents and for the handling and use of its products in the marketplace. This projection is required for proper specification of the waste treatment systems and for defining the extent of upgrading required to meet anticipated specifications on product quality. (This projection is to be performed by DOE.)

Each process under consideration shall be designed to meet the following environmental constraints as a minimum:

1. Zero waste water discharge

2. On-oite solid waste disposal conststent with RCRA

3. Propused NBPS for afrborne emissions.

In Phase 0, rigorous adherence to the above environmental constraints is not expected, but comment on any deviations from these standards will be provided.

Following preparation of factored cost estimates for each process, it is intended that economic analyses according to DOE-supplied financial guidelines be performed and a summary report giving brief process descriptions, capital costs, operating costs, etc., be prepared. The report will also include an assessment of (1) the state of development of each process, (2) the adequacy of the data base, (3) the range of uncertainty of the cost estimates, (4) the relative probability that the process wlll uperate successtully as designed, and (6) the potential impacts of future development work on the proness economics.

It is anticipated that the draft report for Phase 0 will be completed by July $1,1979$.

\section{References for Section 6}

1. W. R. Williams, J. R. Horton, W. F. Boudreau, and M.'Siman-Tov, Survey of Industrial Coal Conversion Equipment Capabilities: Rotating Components, ORNL/TM-6074, Oak Ridge National Laboratory, April 1978, p. 86. 


\section{PROCESS AND PROGRAM ANALYSIS}

R. W. Glass

Process and program analysis studies are being conducted for the DOE Fossil Energy Engineering Economics and Standards Section of the Planning and Systems Engineering Division. This effort includes research studies on most of the coal conversion and utilization processes. The program objective is to provide on a consistent basis, technical and economic evaluations of competing processes and systems for coal conversion and utilization.

\subsection{In Situ Coal Gasification}

M. S. Edwards and W. C. Ulrich

\subsubsection{Contract Objective}

The objective of this program is to provide technical and economic evaluations of candidate processes for the conversion of coal in situ to fluid products presently of interest. During FY 1977, technical and economic evaluations of the linked vertical well process applied to subbituminous coal were addressed. Three alternative end product configurations were considered - electricity, SNG, and syngas. In FY 1978, an evaluation was conducted of an in situ facility for producing gasoline from methanol via the Mobil-M process.

\subsubsection{Status Summary}

The draft 1977 report, Process Designs and Economic Evaluations for the Linked Vertical Well In Situ Coal Gasification Process, ORNL5341, and the draft 1978 report, Evaluation of an In Situ Coal Gasification Facility for Producing M-Gasoline via Methanol, ORNL-5439, are in the final stages of preparation. Drawing and figure corrections have been submitted to the Drafting Department. Distribution lists have been prepared. A paper, entitled "Economics of Gasoline Production from Underground Coal Gasification via Mobil-M Process," was presented at the AIChE meeting, Houston, Texas, April 1-5, 1979, giving the principal results of the 1978 report. A condensed version of this paper was provided to Chemical. Engineering Progress at their request for inclusion in the next issue of the CEP Coal Processing Technology technical manual. 


\subsection{HYGAS Modeling}

J. P. Meyer, G. C. Frazier, J. W. Wells, and J. P. Belk

\subsubsection{Contract Objective}

The objective of this project is to develop a computer model of the HYGAS gasifier.

\section{2 .2 Status Summary}

A copy of the HYGAS draft final report Mathemat1cal Model of the HYGAS Pilot Plant Reactor (ORNL-5475) has been forwarded to DOE for review and comment, but material to be included in the Appendix was not included. That material has been transmitted to DOE and final revision and publication is expected during the next quarter.

\subsection{Liquefaction}

R. W. G1ass

\subsubsection{Contract Objective}

The objective of this project is to provide technical and economic evaluation of coal conversion liquefaction processes. Ralph M. Parsons Company is working under subcontract on the project with J. B. O'Hara as Project Manager. Major tasks included in the subcontract are: (1) a Survey of Liquefaction Processes, and (2) a Detailed Review of High Potential Liquefaction Processes.

\subsubsection{Status Summary}

The revised final draft report for this project, Liquefaction Technology Assessment (ORNL/Sub-7186-30) has been received from Parsons and has been subjected to detailed internal review at ORNL. Copies have also been made available to DOE and comments of both review organizatione will be forwarded to Parsons for inclusion in the final report. Issue is expected in 3 to 5 weeks. 


\section{7:4 High Btu Gas}

R. W. Glass

\subsubsection{Contract Objective}

This subprogram is being analyzed under subcontract by the Scientific Design Company, Incorporated (SD) with A. S. West as Project Manager. The present work is divided into three phases as follows:

1. The objective of Phase $I$ is to provide technical and economic evaluations of competing processes, concepts and systems for the production of high Btu gas from coal.

2. The objective of Phase II is to monitor and analyze data from the HYGAS Pilot Plant.

3. The objective of Phase III is to perform a technical and economical evaluation of the Battelle Agglomerating Ash Burner Process for the production of medium Btu fuel gas, synthesis gas and hydrogen from coal.

\subsubsection{Status Summary}

As mentioned in previous progress reports, Phase I activities in this project have resulted in the issue of a final report, Battelle Agglomerating Ash Burner Process for High-Btu Gas Applications, ORNL/Sub$7240 / 1$. Further evaluation of the Battelle process for medium-Btu gas applications (Phase III) has also been completed and suggested changes in the draft report following ORNL staff technical review have been forwarded to SD.

At IGT's HYGAS pilot plant, Test Run No. 78 (the second to process run-of-mine Illinois No. 6 bituminous coal) was initiated at 0330 hours on February 10 and became self-sustaining at 2115 hours on February 25 . This delay was caused by major mechanical difficulties which were summarized in the last monthly report. A feed slurry leak, coupled with uncontrollable bed levels in both the slurry dryer and the low temperature reactor, forced termination of the test at 1000 hours on March 11.

A post-run inspection was carried out by IGT, beginning March 15, with the following observations recorded by SD engineers on site.

Plant operations: coal milling and drying

Major damage to the coal mill, discovered shortly after initiation of the test resulted in substantial reduction of milled coal production. This required continuous operation to build up a coal inventory for short periods of gasifier operation. 
Other problems with the coal mill included frequent stoppages from tramp metal (either in the rotary feeder feeding the mill or in the mill itself) and the dropping of a roller from one of the journals on two occasions. Practically all of the metal particles that gave problems were magnetic, so removal prior to the milling operation should be a simple task.

Since the weather was mild during the period, wet coal did not cause the problems in the rotary feeders and SWECO screens that occurred during Test No. 77.

The reduced capacity of the mill prevented steady operation in other sections of the pilot plant.

\section{Plant operations: coal pretreatment}

The problems in the coal mill prevented steady operation of the pretreater so no real conclusions can be drawn; however, it appeared that overall operation of the pretreater was improved over performance during Test No. 77.

The fines SWECO screen tore on two occasions when the body twisted upon the base. This has occurred in the past and steps should be taken to prevent future repetitions of such failures.

The initial performance of the new Sankyo Weigh System appeared to be better than the Merrick Weigh Belts, with errors ranging from $-3 \%$ to $+10 \%$. This is still not sufficiently accurate for the data required. Resorting to such indirect determination of mass rate is not necessary or appropriate, since direct batchwise woighing io more accurate and reliable.

\section{Plant operations: gasification}

Leaks in the low pressure slurry loop occurred on four occasions during the test. A solution must be found to eliminate these frequent leaks to allow continuous gasifier performance. The entire low pressure slurry loop should be redesigned and proper piping selected to prevent these leaks.

Phase 1 and 2 objectives conditions (except for the Sog temperature) appear to have been approached very brlefly for two periods totaling 11.5 hours and one period of 10.5 hours, respectively. Phase 3 conditions were not attempted. Both Phases 2 and 3 will be repeated in Test No. 79. Solids transfer problems plagued gasificr operation throughout the test. These were undoubtedly intensified by the stop and go operation necessitated by the problems with the coal mill. 
Despite the high superficial velocity at mild SOG temperatures, a clinker was found in the SOG during post-run clean-up operations. The clinker was loose in the remaining char, but appears to have been attached to the wall of the gasifier approximately $I^{\prime \prime}$ above the top of the sparger riser tube and directly above the sparger inlet pipe. Cycling of thermocouples during the test apparently indicated the formation and subsequent removal, probably by erosion, of clinker at these locations.

In conclusion, $S D$ believes that insurmountable solids transfer problems in the gasifier, rather than quench/slurry leaks, were responsible for the failure of Test No. 78 to achieve planned objectives. The schedule for Test No. 79 remains indefinite.

\subsection{Direct Combustion}

E. C. Fox and T. D. Anderson

\subsubsection{Contract objectives}

The purpose of this study program is to assist DOE/FE in their effort to develop a national strategy to increase the near-term use of coal through direct combustion; the applications of interest in this study are the small-to-moderate industrial user and the large residential/commercial user. The following objectives will be accomplished.

1. Identify and quantify the important factors restricting the use of coal in the sectors of interest.

2. Evaluate potential technological and institutional solutions to the problems identified in (1) above.

3. Make recommendations to DOE/FE relative to the most promising approaches to increasing the near-term use of coal.

\subsubsection{Status summary}

The report entitled "Conversion to Coal in the Industrial Sector," ORNL/TM-6131, is being prepared for publication. 


\subsection{Advanced Power Conversion Systems}

J. E. Jones Jr. and A. P. Fraas ${ }^{a}$

\subsubsection{Contract objective}

The objectives of this project are to revlew selected major advanced power conversion systems and to assess these systems with respect to their basic R\&D status.

\subsubsection{Status summary}

A total of eleven systems or compnnents of oyotems were evaluaced. Draft reports covering all of these topics, an overall sumuary report, and an executive summary report have been completed and are undergoing final review.

$\overline{a_{\text {Consultant }}}$ 


\section{FOSSIL ENERGY ENVIRONMENTAL PROJECT}

C. R. Boston

The Fossil Energy Environmental Project provides DOE with program assistance in the performance of environmental assessment functions related to the expansion of fossil energy conversion technologies, performs assigned technical assistance tasks, and conducts programmatic environmental investigations that are critical to the early realization of advanced fossil energy technologies.

\subsection{Stored Solids Study}

W. J. Boegly, Jr.

All planned physical and chemical characterization of Grace/Ebasco solid waste has been completed. Tentative data analysis indicates that this waste will be classified as non-hazardous, according to the proposed rules for implementation of the Resource Conservation and Recovery Act, as published in the December 18, 1978 edition of the Federal Register. Because of the uncertainty of the final form of these rules, a firm conclusion cannot be made at this time.

Another shipment of Grace/Ebasco waste from runs made in February, 1979 is en route to ORNL at this time. These runs were made using Kentucky $\$ 9$ coals from the Colonial $\$ 9$ and Zeigler \#9 mines.

Major efforts were made during the month to obtain soil and geology data for the Grace/Ebasco CONOCO and MLGW demonstration plant sites prior to site visits to collect soil samples for attenuation studies in the laboratory. A visit to the Henderson, KY. site of the Grace/Ebasco demonstration plant is planned for mid-May. We have received excellent cooperation from county soil conservationists in these areas.

Meetings were held with Carole Szpunar, Exxon Research and Engineering Company, Baytown, Texas, and with George Heunish, CONOCO Coal Development Company, Library, PA. during the month. Ms. Szpunar is becoming involved with solid waste studies at Exxon and wanted to find out what directions our efforts have taken in this area. Mr. Heunisch was here to review our work on the British Gas/Lurgi solid waste characterization and to discuss available information that could be of help prior to the soil sampling trip to the CONOCO demonstration plant site. 


\subsection{Coal Conversion Demonstration Projects}

\subsubsection{Liquefaction projects - S. G. DeCicco}

SRC-I - The highlight of our activity this month was a meeting with Southern Company Services, Air Products, Rust Engineering, Dames \& Moore, and DOE-ORO in Birmingham, Alabama. The topic of discussion was the determination of process alternatives for consideration in the EIS. Following the discussions in this meeting ORNL prepared a preliminary list of alternatives and strategy for treating them in the EIS.

SRC-II - A mepting hetraen ORNL, OB.O, Stoarno-Roger; and Gulf Mineral Resources (GMRC) was held to review the proprietary "White Book" (conceptual process design) and discuss possible process alternatives that could influence the performance of the plant from an environmental standpoint. GMRC is preparing a preliminary list of alternatives for ORNL review.

\subsubsection{Gasification projects - A. J. Witten}

Grace/Ebasco - The Notice of Intent (NOI) and Implementation Plan (IP) are complete and have been transmitted to headquarters. The NOI has not yet appeared in the Federal Register, however, the Scoping Meeting is still scheduled for May 16.

The staff has reviewed the site selection study for Grace and found it to be inadequate for the alternatives section of the ER.

MLGW - Draft ER sections on ambient noise have been received and are out for team review. The ER schedule has apparently slipped again and the delivery date for the Final ER to ORNL is now Sept. 1, 1979.

CONOCO - DOE approval of our recommended spawning study has been deferred until State concurrence has been received. Similarly, approval of the recommended soil survey has been deferred until the site visit scheduled for May 24. The environmental subcontractor has established that 40 samples would be required for this study, at about $\$ 90$ per sample.

ICGG - A continuous stream of Draft ER sections has been received and team review is proceeding. Work has begun on the preparation of the NOI and IP. 


\title{
8.3 Gasification Test Facility (GTF)
}

\author{
S. G. DeCicco
}

All prepatory work to implement a monitoring program at the prime site was completed in recent months. Further activity on this project now awaits project authorization by DOE. DOE-CH has expressed interest in having ORNL assist them in a new site suitability study for the project. We received a response from DOE to a list of questions regarding the environmental aspects of the conceptual process design.

\subsection{Atmospheric Fluidized Bed Combustion (AFBC)}

\author{
S. G. DeCicco
}

\subsubsection{Technology assessment}

No significant activity this month.

\subsubsection{TVA's demonstration project}

A meeting was held with TVA at which ORNL presented recommendations for preparing an Environmental Impact Assessment (EIA) for the $10 \mathrm{MW}$ pilot AFBC facility, an Environmental Impact Statement (EIS) for the 200 MW demo AFBC facility.

\subsection{Processing of Coal Conversion Wastes for Disposal and Resource Recovery}

R. M. Canon, G. Jones, Jr., and J. S. Watson

Tests have begun on several gasification resldues. One matcrial was tested with a direct leach of sulfuric acid and also with the Calsinter process. This process consists of a sintering step with $\mathrm{CaSO}_{4}$ and $\mathrm{CaCO}_{3}$ to release the metal values from the silica, followed by sulfuric acid leaching. The direct acid leach was almost completely ineffective on that material and recovered only $2 \%$ of the aluminum after a $16 \mathrm{hr}$ leach at $105^{\circ} \mathrm{C}$. The material appears to be one of the most inert tested to date, even more resistant to attack than fly ash. However, the Calsinter process recovered about $90 \%$ of the aluminum from the material.

Preliminary studies with residue from another gasifier waste have shown the metals to be quite easily recovered with a direct acid leach (sulfuric acid). Approximately $95 \%$ of the aluminum and $100 \%$ of the iron were recovered in a $16 \mathrm{hr}$ leach of this material. This residue contains about $18 \%$ calcium, much of it present as unreacted lime, and 
this results in the formation of large amounts of $\mathrm{CaSO}_{4}$ solids during the leach. Further tests with this material are planned, including its use in the Calsinter process. Work on a third gasifier ash has also just begun and preliminary results indicate that this residue is also susceptible to direct leach with sulfuric acid. This material, as with the second material, appears to release $\mathrm{H}_{2} \mathrm{~S}$ when reacted with the acid. Studies using both materlals are also continuing.

The primary effort to date has been the development of an analysis technique to utilize $x$-ray fluorescence (SRF) for the rapid, accurate analysis of both solid and liquid samples. This method will enable us to analyze for 25 elements, including trace metals, for about the cost of a single wet chemical or atomic absorption analysis. Development work is almost complete for the solid phas samples and is in progress for liquids. Use of XRF will permit us to obtain reliable results on these trace elements for a large number of samples. 


\section{MAGNETIC PREPARATION OF DRY CRUSHED COAL \\ E. C. Hise \\ A. S. Holman}

\subsection{Objective}

The objective of this program is to develop, demonstrate, and bring to commercial viability the removal of pyrite and ash-forming minerals from dry crushed coal by either or both processes of high-gradient magnetic separation and open-gradient magnetic separation.

\subsection{Status Summary}

The magnetic preparation staff witnessed a demonstration at the manufacturer's plant of the start-up procedure and operation of the purchased laboratory superconducting magnet. The staff was instructed in the techniques and procedure for liquid nitrogen and helium transfer, for cooling the cryostat and magnet coil to liquid helium temperature, and for operating the power supply and energizing the magnet over its range of field strength. The design expectation was a maximum field strength of six Tesla, with a guarantee of four Tesla. The magnet actually achieved 6.6 Tesla. The manufacturer then demonstrated the integrity and self-protection of the system by raising the current above the capacity of the magnet, at which point it quenched and boiled the helium out. This is, of course, not a recommended procedure but is a reassuring demonstration.

Mr. W. O. Thomas of TVA-Chattanooga has joined Mr. Smith on guest assignment to our laboratory. Mr. Thomas has been assigned to evaluate methods of classifying (sizing) the raw coal for a coal preparation plant and will be performing related experimental work here.

A mathematical model of the laboratory open-gradient separator is operational. It accepts inputs for particle size, density, magnetic susceptibility, and initial velocity; for transport gas velocity, density, and viscosity; and for magnetic field strength, gradient, length, orientation, point of maximum field, and point of particle entry. It outputs for each described particle the position, force, velocity, and acceleration at 500 intervals of vertical position. Thus, the model can perform parametric analyses of particle trajectories for variations of particle size and nature, of still or moving gas at pressure to vacuum, and of field strength, configuration, and orientation. The mathematical predictions for several cases have been experimentally verified. In one case the calculations revealed an operating problem that had not been anticipated or observed in the experimental operation and provided a solution.

A similar mathematical model is now being developed for the Solenoid magnet. 


\section{ATMOSPHERIC FLUIDIZED BED COAL COMBUSTOR FOR COGENERATION (AFBCCC)}

R. S. Holcomb

\subsection{Objective}

The Coal Combustor for Cogeneration (CCC) Program is directed at the development of a fluidized bed coal combustion system heating air inside tubes to provide high temperature clean air to drive a gas turbine to generate electricity. The heat in the air leaving the turhine exhanst would be recovered to supply industrial process heat. The gas turbine is very well suited for cogeneration since the ratio of thermal to electrical energy is about 3 to 1 for the gas turbine cycle as compared to a ratio of about 5 to 1 for a back-pressure steam turbine, and the exhaust heat from the gas turbine is available at a higher temperature. The scope of the program includes the study of industrial cogeneration plants in the size range from 5 to $50 \mathrm{MW}(\mathrm{e})$ and the construction and testing of a $0.3 \mathrm{MW}(\mathrm{e})$ technology test unit.

\subsection{Status Summary}

Interest in the CCC Program RFP continues to run very high among potential contractors. Indications are that the number of proposals submitted may be higher than had been expected at the time the RFP was issued.

One of the vendors requested an additional two-week extension of time for submitting a proposal. They needed more time to make a satisfactory estimate of the costs of the program. The proposal submission deadline has been extended to May 31, and all the prospective vendors have been notified. 


\section{TENNESSEE VALLEY AUTHORITY (TVA) FLUIDIZED BED COMBUSTION (FBC) DEMONSTRATION PLANT PROGRAM \\ TECHNICAL SUPPORT}

J. E. Jones $\mathrm{Jr}$.

Tennessee Valley Authority has assumed a lead role in the demonstration of FBC technology for application in large utility boilers. ORNL will provide technical support and services to TVA in FBC systems. This work is to support TVA Energy Research's objective to develop FBC systems for utility electric power generation which will burn high sulfur coal and meet environmental emission standards.

TVA will be the lead agency in this work and will reimburse DOE for the work to be performed by ORNL. This work is to be conducted by ORNL under the terms and conditions of the Interagency Agreement between TVA, DOE, and ORNL regarding support for FBC research (reference: Agreement TV48296A, Subagreement 5).

\subsection{AFBC Technology Support - Task 2 \\ M. Siman-Tov and J. E. Jones Jr.}

\subsubsection{Contract objective}

The objective of this program is to provide technical support of a general nature in FBC systems and respond to specific requests from TVA personnel. Such requests may include reviews, assessments, participation in TVA tasks, and similar activities.

\subsubsection{Status summary}

No activities on this task during the past month. 


\section{$11.24 \times 4$ Cold Flow Model - Task 3}

R. S. Holcomb and M. E. Lackey

\subsubsection{Contract objective}

The objective of this task is to experimentally investigate slumping of a portion of a fluidized bed using a sub-scale cold flow model. The scope of work includes design and minor modification of the $4 \mathrm{ft} \times 4 \mathrm{ft}$ cold flow model for slumping and refluidization tests and conducting bed slumping tests.

\section{2 .2 Status summary}

Design and moditications - The fluidizing air plenum wili be redesigned so that the air can be shut off to a portion nf the $4 \times 4$ bed with the air flow continuing to the other portion. A new simulated tube bundle will be designed for the slumping tests. The design will be based on a $1 / 4$ scale factor - i.e., the tube diameter, bed depth, and fluidizing velocity will be $1 / 4$ that of the full-scale FBC boiler. The cold flow model will be modified to incorporate the design changes.

Testing - Tests will be conducted to investigate the effects of slumping a portion of the bed and continuing operation of the remainder. Observations will be made to study mixing between the active and slumped portions, fluidizing air bypass through the slumped section, elutriation from the fluidized section and deposit in the slumped section, and maximum buildup of the slumped bed. The fluidizing air will then be turned on to the slumped portion, and the action of the two sections will be studied during refluidization. These tests will be done over a range of fluidizing velocities from 1 to $2 \mathrm{ft} / \mathrm{sec}$ and bed depths from 1 to 1.5 ft to represent scale studies of values four times as large. Other operating data will be obtained incidental to these tests.

Progress to date - The installation of the new inlet air piping was completed this month. The bed was filled with limestone to a depth of about $18 \mathrm{in.,}$ and system checkout tests were run. The bed was fluidized at a velocity of $1-2 \mathrm{ft} / \mathrm{sec}$ and then the air was turned off to one half of the bed, with half of the air bypassed so that a constant velocity was maintained through the active half of the bed. The system was run for a period of about 15 min with one half of the bed slumped. There was some solids buildup in the slumped section near the edge of the active portion, but the deep tube bundle presently in the bed appeared to affect the solids movement so that no definite conclusions could be reached about the performance of the slumped bed. The air flow was restored to the slumped portion after each test and fluidization was quickly reestablished.

Fabrication of the new mockup tube bundle was completed. It will be installed next month, and slumping tests will be initiated. 


\subsection{AFBC. Modeling and Simulation - Task 4}

M. Siman-Tov and J. W. Wells

\subsubsection{Contract objective}

The objectives of this program are to develop a simple steady-state model for conceptual design of the main cell and carbon burn-up cell and to incorporate in this model the ability to predict trends in bed performance under various feed and operating parameters.

\subsubsection{Status summary}

C. Y. Wen's computer code for simulation of AFBC combustors was received and implemented on the PDP-10 and IBM systems at ORNL. Documentation of this code (NASA Report No. CR-159529) was received during the last week of this month. Inputs simulating the TVA 200 MWe boiler, as specified by Babcock and Wilcox ${ }^{1}$, are being prepared. This code will be tested during the next month with these data.

Cooperation with MIT has continued. Discussions via telephone were held with Professors Sarofim and Tung at MIT. The existence of possible numerical problems in MIT's combustion submodel was discussed. As a result, it was suggested that the input data necessary for simulation be sent to MIT. This information will be run on the full MIT code and the results returned to ORNL. Accordingly, the inputs for simulating the Babcock \& Wilcox 200 MWe boiler $^{1}$ have been sent to MIT. This action was cleared with C. Sadler of TVA.

Also, a review of combustion kinetics of coal was made. This included the work of Fields ${ }^{2}$ and Smith $^{3-6}$ and established a lack of kinetic data on the combustion of bituminous coal chars. As a result, a letter recommending an experimental program to study the kinetics of bituminous char was drafted and will be submitted in the coming month.

The hydrodynamic phenomenon of bed expansion and bubble size distribution in large fluidized beds was investigated. Specifically, the results from the IGT bed expansion equation ${ }^{7}$ were compared with those of Staub $^{8}$ and Modrak ${ }^{9}$. This showed that the IGT equation predicted the bed expansion within $t 12 \%$ of the experimental value. Equations were derived which relate the bed voidage to the bubble diameter (which is a function of height). During the next month, a bubble growth equation will be numerically fitted to give the bed expansion calculated via the IGT equation. The results will then be analyzed.

A presentation outlining the current project effort was given this month at the Engineering Technology Division's Fossil Energy Program Review Meeting. 


\subsection{AFBC Bench Scale Model - Task 5}

R. S. Holcomb, R. H. Guymon, and G. P. Zimmerman

\subsubsection{Contract objective}

The objective of this task is to experimentally investigate heat transfer, sulfur capture, carbon loss, and combustion of recycle carbon using the ORNL AFBC bench scale combustor.

\section{4 .2 Status summary}

Test facility description - The combustor is $10 \mathrm{in.}$ ID and about 15ft tall. The combustor is designed for burning 10 to $30 \mathrm{lb} / \mathrm{hr}$ of coal and is equipped for limestone addition. The system is designed to operate with a bed fluidizing velocity in the range of 4 to $10 \mathrm{ft} / \mathrm{sec}$ and bed temperatures up to $1600^{\circ} \mathrm{F}$. The bed is cooled by compressed air flowing through 0.5 in. OD tubes immersed in the bed.

Test program-Heat transfer tests will be done for 1000 and $1900 \mu \mathrm{m}$ mean size limestone over the fluidizing velocity range of 4 to $10 \mathrm{ft} / \mathrm{sec}$ at bed temperatures of $1400-1600^{\circ} \mathrm{F}$. Sulfur capture and carbon loss tests will be run for selected coals and limestones of interest to TVA for several values of $\mathrm{Ca} / \mathrm{S}$ over a fluidizing velocity and temperature range similar to that for heat transfer. Tests to investigate the combustion of recycle char removed by the cyclone separator will be run for various operating conditions.

Progress to date - The combustor was out of service this month. It was disassembled and a number of modifications were made. Six additional thermocouples were installed to measure air and bed temperatures on the air-cooled bed heat exchanger in an effort to obtain improved data and a better understanding of the heat transfer performance. Two gasketed circumferential joints on the combustor freeboard housing were seal welded to eliminate air inleakage at those points. Three additional pressure taps were installed in the bed region. A transparent plastic coal feed hopper was installed. The coal feed level in the hopper was calibrated in terms of the weight of coal so that the quantity of coal fed to the combustor can be measured for a period of time.

The drawings for the limestone screw feeder were sent to the shop, but fabrication has not been completed. It is now expected that the limestone feeder will be installed by about May 20. It is planned to fill the combustor with $12 \times 30$ mesh 1 imestone and run the combustor until that batch of limestone has been fairly well sulfated, as indicated by $\mathrm{SO}_{2}$ emission level. After the 11mestone feeder has been installed, testing will be initiated with continuous limestone addition. 
11.5 Assessment of the State-of-the-Art of PFBC Systems - Task 6

R. L. Graves, M. E. Lackey, and A. P. Fraas $^{a}$

\subsubsection{Contract objective}

The purpose of this program is to provide TVA with an assessment and overview of the state-of-the-art for PFBC systems and their associated components.

\section{$11: 5.2$ Status summary}

The pressurized fluidized bed parametric study was given primary attention this month. The steam system model was completed, debugged, and tested successfully. An interface between the steam system and furnace/gas turbine system was developed to take into account the feedwater heater configuration which must be changed depending on the need for an economizer which cools the turbine exhaust gases by heating the boiler feedwater.

The first test case was an atmospheric pressure combustor system. The calculated net thermal efficiency was $35.8 \%$, which is in agreement with that reported for comparable systems. A $0.10 \mathrm{MPa}$ (10 atm) PFBC system was found to have an overall efficiency of about $39.8 \%$ when the inlet temperature of the gas turbine was set at $900^{\circ} \mathrm{C}\left(1650^{\circ} \mathrm{F}\right)$.

\subsection{Analytical Support and Alternate Design Concepts Evaluation - Task 7}

$$
\text { E. C. Fox }
$$

\subsubsection{Contract objective}

The objectives of this task are to assist TVA in determining the design parameters which are critical to an effective AFBC system from the standpoints of efficiency and cost and to provide direction as to better design options.

\subsubsection{Status summary}

Work this month was restricted to preliminary calculations to determine the change in busbar cost as a function of design parameters and $\mathrm{SO}_{2}$ standard. The calculations are being used to determine which design parameters are the most important.

$a_{\text {Consultant }}$ 


\subsection{AFBC Technical Source Book and R\&D Evaluation - Task 8}

M. Siman-Tov and A. A. Khan

\subsubsection{Contract objective}

The objectives of this program are: 1) to develop a single comprehensive source book of technical data for design procedures and evaluation of AFBC facilities and programs, 2) to review and evaluate existing and proposed AFBC facilities to perform research and development for TVA, and 3) to interpret and translate results of test studies performed for TVA and turther the knowledge in $\mathrm{AFBC}$ research and development activities.

\subsubsection{Status summary}

Design information for fluidization parameters has been reviewed as outlined in Table 11.1 .

Also, some of the work and capabilities of R\&D facilities have been reviewed from available literature. These facilities are: Babcock \& Wilcox's 6-ft by 6-ft plant, Combustion Engineering, PER's Alexandria . unit, Battelle, and the National Coal. Board with R\&D work at the Leatherhead facilities. The summary is still being prepared for these reviews. It should be noted that published information from the major boiler manufacturers was scarce.

Next month the design Informacion from Geldarc's and Zenz's notes. w111 be summarized. Also, heat transfer correlations will be obtained. The information obtained this month will be rewritten in a summary form.

\subsection{Materials Support for TVA Pilot and Demonstration AFBC Plants.- Task 9}

T. G. Godfrey, J. H. DeVan, and R. A. Bradiey

\subsubsection{Contract objective}

ORNL proposes to assist TVA technically in the materials area. The unique part of an AfBC is the fluidized bed combustor and 1is assoclated hardware, since the balance of the plant closely resembles a conventional pulverized-coal supply system. The principal areas of concern are the in-bed heat-exchanger tubes and hangers, the air distributor, side walls, coal feed lines and nozzles, spent-bed removal hardware, and cyclones for separating elutriated material. 
Table 11.1. Summary of literature reviewed.

\begin{tabular}{|c|c|c|}
\hline Author & Topic & Applicability to AFBC \\
\hline $\begin{array}{c}\text { Babcock \& Wilcox } \\
\ldots\end{array}$ & $\begin{array}{l}\text { Minimum fluidization } \\
\text { velocity and terminal } \\
\text { velocity }\end{array}$ & $\begin{array}{l}\text { To get design parameters for } \\
\text { limits of operation of super } \\
\text { ficial velocity for a size } \\
\text { of particles in the bed. }\end{array}$ \\
\hline Argonne Lab & $\begin{array}{l}\text { Minimum fluidization } \\
\text { velocity }\end{array}$ & $\begin{array}{l}\text { Verification of Ergurn } \\
\text { equation and quality of } \\
\text { fluidization for dolomite } \\
\text { beds. }\end{array}$ \\
\hline $\begin{array}{l}\text { Leung, ITT, } \\
\text { British }\end{array}$ & $\begin{array}{l}\text { Design of perforated } \\
\text { distributor tray }\end{array}$ & $\begin{array}{l}\text { Design of a tray for a } \\
\text { bubble size (less than } 1 \\
\text { meter diameter). }\end{array}$ \\
\hline Geldart, Wen & $\begin{array}{l}\text { Hydrodynamics of } \\
\text { fluidized beds }\end{array}$ & $\begin{array}{l}\text { Bubble growth for different } \\
\text { sizes of particles used in } \\
\text { AFBCs. However, restricted } \\
\text { to small diameter size. }\end{array}$ \\
\hline Highley & $\begin{array}{l}\text { Circulation of large } \\
\text { coal particles }\end{array}$ & $\begin{array}{l}\left(U-U_{m f}\right) \text { has to be exceeded } \\
\text { beyond a certain limit to } \\
\text { prevent segregation. }\end{array}$ \\
\hline $\begin{array}{l}\text { Exxon Research } \\
\text { Center }\end{array}$ & $\begin{array}{l}\text { Sulfur absorption } \\
\text { on lime }\end{array}$ & $\begin{array}{l}\text { Temperature to get maximum } \\
\text { sulfur capture. }\end{array}$ \\
\hline $\begin{array}{l}\text { Merry, Grace } \\
\text { and rijt }\end{array}$ & $\begin{array}{l}\text { Entrainment of } \\
\text { particles in } \\
\text { fluidized beds }\end{array}$ & $\begin{array}{l}\text { Jet penetration to avoid } \\
\text { contacting the tube bundles. }\end{array}$ \\
\hline $\begin{array}{l}\text { Field, Caram \& } \\
\text { Ammdson, Smith }\end{array}$ & $\begin{array}{l}\text { Kinetics of coal } \\
\text { burning }\end{array}$ & $\begin{array}{l}\text { Rate equations for coal } \\
\text { burning. }\end{array}$ \\
\hline MIT & Modeling & Devolatilization of coal. \\
\hline $\begin{array}{l}\text { Bogardt, } \\
\text { Argonne Lab }\end{array}$ & $\begin{array}{l}\text { Kinetics of } \mathrm{SO}_{2} \\
\text { capture }\end{array}$ & $\mathrm{Ca} / \mathrm{S}$ versus flow parameters. \\
\hline Beer, et a1 & $\mathrm{NO}_{x}$ removal kinetics & $\mathrm{NO}_{\mathrm{X}}$ reduction rates. \\
\hline
\end{tabular}




\section{8 .2 Status summary}

During the past month we, together with R. H. Cooper (ORNL) and W. D. Goins (TVA), have developed a summary listing of possible material technology gaps in the design of atmospheric fluidized bed combustors. Trips were made to EPRI and DOE-Headquarters for detailed discussions with John Stringer and S. J. Dapkunas, respectively, about the listing and our priority ranking of the individual items. All comments received are being incorporated into a second draft of the listing which will subsequently be more broadly distributed for additional comments.

While at EPRI, we discussed with Stringer a slumped-bed muffle furnace experiment which we propose to conduct at ORNL. 'Ihis test is very similar to "crucible" experiments done by Stringer several years ago in which he demonstrated (to his satisfaction) that alloy samples in contact with C.P. $\mathrm{CaSO}_{4}$ powder at low oxygen partial pressure experienced sulfidation/oxidation corrosion similar to that observed on samples exposed in an AFBC. He acknowledged that the original experiments were rather crude and need to be repeated under more carefully controlled conditions. This is our intention for the ORNL experiments. We will employ either $\mathrm{CO} / \mathrm{CO}_{2}$ or $\mathrm{SO}_{2} / \mathrm{SO}_{3}$ mixtures to set the relative oxygen and sulfur activities over alloy samples in both the presence and absence of $\mathrm{CaSO}_{4}$. This will determine the validity of the assertion by Stringer that sulfated bed material is requisite for sulfidation/oxidation corrosion to occur. The details of our program are currently being developed.

Sections of the $13 / 4-$ in. dia heat-exchanger samples from the Ilrst 1000-hr test at CURL (Leatherhead, England) have been received at OKLVL and are being prepared for metallographic and electron microprobe examination. In the main, the samples are covered with a sulfate scale that is much thicker than we observed on the $\frac{1}{z}$-in. dia tubes from the ORNL tests at Fluidyne. Cursory examination reveals no evidence of fireside corrosion.

\subsection{Dynamic Modeling of the TVA Fluidized Bed Combustion Demo Plant - Task 10}

N. C. Bradley and 0 . L. Smith

\section{I1.y.1 Contract objective}

The objective of this task is to provide dynamic modeling and transient systems analysis directly applicable to the TVA pilot plant. As an important benefit, the information obtainable from a dynamic model would help in the specification of such features as function, range, and type of instrumentation required to provide the desired plant operating characteristics. 


\section{9 .2 Status summary}

The dynamic model of the TVA pilot plant is now being used to investigate the generic open-loop behavior of fluid-bed steam generators similar to the anticipated TVA design. All known programming difficulties have been resolved, including in particular the previously reported problem with the nonlinear algebraic equation solving code, HYBRDl. Several dozen calculations have been made of potential system disturbances. Most of these were completed at the end of the current month, and time does not permit preparation of proper tabular display. Reporting of specific results will therefore begin next month. An automatic plotting routine is being added to the model which will hopefully expedite visual presentation of the transient behavior.

The (open-1oop) model presently consists of four major sections. The first calculates plant initial conditions. The second gives the time-dependent response. The third is a "speed-up" routine which causes the simulation to skip to the final equilibrium at a user-preset time. All of these sections were discussed in prior monthly reports. The fourth section, based on first order perturbation theory, provides a sensitivity analysis of the system to any disturbance; that is, it determines the magnitude of variation of all system temperatures, pressures, densities, flow rates, etc., when the system is disturbed intentionally or otherwise by a change in load, firing rate, or whatever. While the transient calculation determines how fast things change, the sensitivity analysis is useful in showing, among other things, how much the system changes. Knowledge of both is clearly required in control system design.

Because a substantial number of calculations are usually needed in coming to grips with system dynamics and because the time constants of steam generators are often large (ten to fifteen minutes), efficiency of the model operation is essential. Previously reported procedures to improve computer running time have proven successful. In an example run of the model, the initial steady-state conditions were calculated, then a $1 / 2 \%$ reduction in load was made followed by a transient calculation of ten minutes of steam generator operatimg time (sufficient to activate all time constants); at that point, the model was instructed to skip to the new equilibrium conditions. Finally, a sensitivity analysis of the load change was made. This sequence of calculations, using all four sections of the model, required ten seconds of computer time at a total cost of $\$ 1.42$.

Although the various sections are intended to perform different functions, it was possible to devise a steady-state test problem which all four sections could be made to calculate. In the case of no disturbance, the transient calculation should show the system unchanging indefinitely, the final equilibrium "speed-up" equations should give identically the initial conditions, and the sensitivity analysis equations should show zero change in all variables. This proved to be true in the test problem. All four model sections gave the same answer, providing a consistency cross-check against programing error. 
Additional features added include explicit calculation and printout of heat exhausted through the stack and spent bed material as well as the quantities of heat stored in system components (evaporator metal, superheater metal, bed material, etc.). This information bears directly on system time constants and therefore on transient behavior.

\subsection{References for Chapter 11}

1. W. A. Hansen, Conceptual Studies and Preliminary Design of a Fluid Bed Fired Boiler for Service in an Electrical Utility, TVA Contract No. TV-45715A, April 28, 1978.

2. M. A. Field, D. W. Gill, B. B. Morgan, and P. G. W. Hawksley, Combustion of Pulverized Coal, Leatherhead (1967).

3. I. W. Smith and M. F: R. Mulcaim, Rev. Pure and Appl. Chem., 19,81 (1969).

4. I. W. Smith, Combustion and Flame, 17, 421 (1971).

5. I. W. Smith, R. J. Hamor, and R. J. Tyler, Combustion and Flame, 21, 153 (1973).

6. I. W. Smith and R. J. Tyler, Combustion Science and Technology, 9, 87 (1974).

7. S. P. Babu, D. Swan, and A. 'Talwalkar, Al'nt Symposium Sèriès, No. $176,74,176$ (1978).

8. F. W. Staub and G. S. Canada, Procoodings of Second Engineering Foundation Conference, Trinity College, Cambridge, England, p. 339, April 2-6, 1978.

9. T. M. Modrak, T. A. Morris, W. C. Lapple, and C. J. Aulisio, to be presented at AIChE conference at Houston, Texas, April 1979. 


\title{
12. COAL COGENERATION/DISTRICT HEATING PLANT ASSESSMENT
}

\author{
M. A. Karnitz and R. L. Graves
}

\subsection{Objective}

The objective of this work is to provide the Fossil Fuel Utilization Division of DOE with an evaluation of the coal-fired closed-cycle gas turbine as a cogeneration power plant specifically for district heating in the Minneapolis-St. Paul area. This entails a preliminary design study, including a cost estimate. The design study is a cooperative. effort between ORNL, United Engineers and Constructors (UE\&C), and Northern States Power (NSP). Design of an extraction steam system for the same application is being carried out simultaneously by UE\&C and will allow a comparative evaluation of both cogeneration plants. These design studies are part of a considerably larger program involving other divisions of DOE with the objective of evaluating district heating in Minneapolis-St. Paul.

\subsection{Status Summary}

There has been further delay with United Engineers initiating the work on the coal cogeneration plant assessment. There have been additional contractual problems; however, they now appear to be resolved and UE\&C will begin work on May 15, 1979. By the end of May, Northern States Power will submit the work that they have completed on the investigation of siting a new unit at existing facilities.

A final configuration for the combined cycle cogeneration plant has been developed. The model is of sufficient detail to realistically indicate performance and to facilitate cost estimating. The maximum power generation mode of the plant yields a gross cycle efficiency of about $46 \%$. The variable heat/electric ratio model is nearing completion, and work has also begun on the recuperated closed-cycle gas-turbine model. 


\section{FBC INDUSTRIAL APPLICATIONS PROJECT SURVEY}

K. K. Chipley, N. W. Durfee and M. E. Lackey

\subsection{Objective}

Part of Fossil Energy decentralization includes the transfer of FBC industrial applications projects to Morgantown Energy Technology. Center (METC). A review team has been organized by METC to provide a snapshot status with respect to cost, schedule, and technical problems of eight projects being transferred. After reviewing background information of each project, the team visits the contractor site for several days of intensive interaction with the contractor. A report of the findings of each project is then written and issued to METC.

\subsection{Status Summary}

There were no reviews in April. The review team made two reviews in March at the Curtiss-Wright plant in Woodridge, New Jersey. The first was a three-day review of the PFB Pilot Plant Program which includes a small gas turbine technology rig and will have an overall program cost of over $\$ 50$ miliion. The second review was of the Curtiss-Wright prototype culm combustion boiler/heater unit to be built in Shamokin, Pennsylvania. The plant will use anthracite culm as fuel and will provide 20,000 非/hr of steam.

The review team is scheduled to review the Foster-Wheeler prototype culm project in May. That review will be held in Livingston, New Jersey. 
ORNL/TM-6923

\section{INTERNAL DISTRIBUTION}

1. S. I. Auerbach

2. V. B. Baylor

3. M. Bender

4. W. J. Boegly

5. C. R. Boston

6. N. C. Bradley

7. R. A. Bradley

8. J. I. Brand

9. C. H. Brown

10. G. H. Burger

11. J. E. Campbeil

12. D. A. Canonico

13. J. A. Carter

14. K. K. Chipley

15. B. R. Clark

16. H. D. Cochran, Jr.

17. E. Copenhaver

18. K. E. Cowser

19. R. M. Davis

20. M. S. Denton

21. J. H. DeVan

22. D. G. Doherty

23. N. W. Durfee

24. M. S. Edwards

25. D. M. Eissenberg

26. J. L. Epler

27. D. E. Ferguson

28. L. M. Ferris

29. J. F. Fisher

30. R. C. Forrester, III

31. E. C. Fox

32. W. Fulkerson

33. E. L. Fuller

34. W. R. Gambill

35. R. B. Gammage

36. D. A. Gardiner

37. T. M. Gilliam

38. R. W. Glass

39. T. G. Godfrey

40. W. L. Creenstreet

41. M. R. Guerin

42. C. W. Hancher

43. L. A. Harris

44. S. E. Herbes

45. J. R. Hightower

46. E. C. Hise

47. R. S. Holcomb
48. J. M. Holmes

49. J. K. Huffstetler

50. G. R. Jasny

51. R. L. Jolley

52. J. E. Jones, Jr.

53. R. R. Judkins

54. J. R. Keiser

55. 0. L. Keller

56. R. T. King

57. J. A. Klein

58. J. W. Larsen

59. K. H. Lin

60. R. E. MacPherson

61. A. P. Malinauskas

62. G. B. Marrow

63. C. J. McHargue

64-68. L. E. McNeese

69. J. P. Meyer

70. J. E. Mrochek

71. P. Nettesheim

72. J. P. Nichols

73. B. Niemann

74. L. C. Oakes

75. C. J. Oen

76. G. E. Oswald

77. L. F. Parsly

78-79. T. W. Pickel

80. W. W. Pitt

81. H. Postma

82. M. T.. Poutsma

83. D. E. Reichle

84. C. R. Richmond

85. L. W. Rickert

86. B. R. Rodgers

87. M. W. Rosenthal

88. T. H. Row

89. W. L. Russell

90. R. Salmon

91. G. Samuels

92. C. D. Scott

93. W. D. Shults

94. V. K. Sikka

95. M. Siman-tov

96. S. P. N. Singh

97. C. B. Smith

98. G. P. Smith

99. I. Spiewak 
100. R. L. Spore

101. J. B. Storer

102. R. A. Strehlow

103. R. W. Swindeman

104. O. K. Tallent

105. I. L. Thomas

106. V. J. Tennery

107. J. R. Thurgood

108. H. E. Trammell

109. D. B. Trauger

110. W. C. U1rich

111. R. I. Van Hook

112. P. R. Vanstrum

113. J. S. Watson
114. J. R. Weir

115. P. R. Westmoreland

116. M. K. Wilkinson

117. D. T. Wilkes

118. L. V. Wilson

119. R. G. Wymer

120. E. L. Youngblood

121. C. S. Yust

122. H. W. Sternberg (Consultant)

123. Patent office

124-128. Laboratory Records

129. Laboratorory Records - RC

130-131. Central Research Library

132. Document Reference Section

\section{EXTERNAL DISTRIBUTION}

DOE-Oak Ridge Operations

133. Office of Assistant Manager for Research and Development

DOE-Denver Project Office, Suite 211, 1075 S. Yukon Street, Lakewood, CO 80226

134. W. L. Nol1

DOE-Office of Fossil Energy, Washington, DC 20545

135. W. T. Bakker

136. E. K. Bastress

137. J. D. Batçhelor

138. D. L. Bauer

139. L. M. Burwe11

140. E. L. Burwell

141. N. P. Cochran

142. R. C. Corey

143. T. B. Cox

144. C. W. De Bella

145. R. H. Fischer

146. J. Forst

147. H. Franke1

148. S. I. Freedman

149. W. S. Harmon

150. H. Jones

151. L. M. Joseph

152. L. Kindley
153. T. K. Lau

154. E. Lievens

1bb. C. Miller

156. J. A. Nardella

157. M. B. Neuworth

158. E. S. Pierce

159. H. E. Poda11

160. J. L. Powell

161. M. Keilly

162. J. Shen

163. A. P. Sikri

164. J. Smith

165. D. K. Stevens

166. W. E. Warnke

167. J. W. Watkins

168. H. L. Weisenfeld

169. P. R. Wieber

DOE-Environment, Washington, DC

170. N. F. Barr

171. R. M. Jimeson

172. W. E. Mott

173. R. W. Wood 
Department of Housing and Urban Development, 4517 th St., S.W., Washington, DC 20410

174. G. S. Leighton

175. J. H. Rothenberg

DOE-Pittsburgh Energy Technology Center, 4800 Forbes Ave., Pittsburgh, PA 15213

176. B. D. Blaustein

177. A. W. Deurbrouck

178. R. E. Hucko

National Science Foundation, 1800 G Street, N.W., Washington, DC 20550

179. Robert Rabin

Tennessee Valley Authority, 1230 Commerce Union Bank Building, Chattanooga, TN 37401

180. J. M. Castleberry 184. Manville J. Mayfieid

181. Randy M. Cole.

182. Barry Goss

183. G. A. Hollindèn

185. Stephen R. Smith

186. Donald $\mathrm{C}$. Thomas

187. Uwe Zitzow

University of Kentucky, Institute for Mining and Minerals Research, 213

Bradley Hall, Lexington, KY 40506

188. Theresa Wiley, Institute Librarian

189: O. J. Hahn

190. J. K. Shau

191. Seymour Alpert, Manager, Process Development Fossil Fuel Department, Electric Power Research Institute, 3412 Hillview Ave., P. 0. Box 10412, Palo Alto, CA 94304

192. Frank Baranowski, Mechanical Technology Incorporated, Crystal Square 4, Suite 310, Jefferson Davis Highway, Arlington, VA 22202

193. Gary L. Baughman, Cameron Engineers, 1315 South Clarkson Street, Denver, CO 80213

194. Harold Beuther, Manager, Catalyst and Chemicals Research, Gulf Research and Development Company, P. 0. Box 2038, Pittsburg, PA 15230

195. N. S. Boodman, U.S. Steel Corp., Applied Research Laboratory, 125 Jamison Lane, Monroeville, PA 15145

196. E. L. Clark, Chemical Engineering Services, 4615 North Park Ave., Chevy Chase, MD 20015

197. William R. Epperly, Exxon Research and Engineering Company, P. 0. Box 101, Florham Park, NJ 07932

198. Jack L. Gregory, Project Manager, TRW Energy Systems, 7600 Colshire Drive, McLean, VA 22101

199. L. R. Harris, National Institute of Occupational Health and Safety, MS 8A-45, 5600 Fishers Lane, Rockwille, MD 20857

200. Everitt Huffman, Manager of Fuel Processing Programs, Southern Company Services, P. 0. Box 2625, Birmingham, AL 35202

201. Martha Koehler, Bechtel Corp., P. O. Box 3695, San Francisco, CA 94119

202. Robert W. Laza, Director, Interim Project Office, Department of Energy, Chicago Operations office, 9800 S. Cass Ave., Argonne, IL 60439

203. W. J. Lochmann, Ralph M. Parsons Co., 100 W. Walnut Street, Pasadena, CA 91124 
204. Walter McGough, Jr., Tetra Tech., Inc., 1911 N. St. Myer Drive, Suite 601 , Arlington, VA 22209

205-210. Morgantown Energy Technology Center, P. O. Box 800, Morgantown, WV 26506 ATTN: The Director

211. Joe Morha11, Heat Research Corporation, 3440 Richmond Ave., Houston, TX 77046

212. Thomas E. O'Hare Department of Energy and Environment, Brookhaven National Laboratory, Associated Universities, Inc., Upton, LI, NY 11973

213. F. N. Peebles, Dean of Engineering, University of Tennessee, Knoxville, TN 37916

214. Kenneth P. Lue Phang, Development Engineering Staff, Tennessee Valley Authority, 220 Liberty Building, Knoxville, TN 37902

215-227. Pittsburgh Energy Technology Center, ATTN: Director for J. 0. Barreca, 4800 Forbes Ave., Pittsburgh, PA 15213

228. Charles B. Sedman, U.S. Environmental Protection Agency, Research Triangle Park, NC 27711

229. Dr. Marion Semchyshen, Director of Research, Materials Research for Molybdenum Development, Climax Molybdenum Research Laboratory, 1600 Huron Parkway, P. O. Box 1568, Ann Arbor, MI 48106

230. W. R. Siegart, Texaco, Inc., 2000 Westchester Ave., White Plains, NY 10650

231. Carl Street, Process Research and Development Division, Mobil Research and Development Corporation, Billingsport Road, Paulsboro, NY 08066

232. Prof. C. V. Wen, Chairman, Department of Chemical Engineering, West Virginia University, Morgantown, WV 26506

233. Dr. Wendel Wiser, Department of Mining and Fuels Engineering, University of Utah, Salt Lake City, UT 84112

234-2̇bU. 'lechnical Information Center. 